\title{
Into Battle Without a Shield: How One Reporter's Use of an Anonymous Source Led to the Creation of a Statutory Reporter's Privilege in Kansas
}

\author{
Christopher C. Grenz
}

\section{INTRODUCTION}

When Dodge City Daily Globe reporter Claire O’Brien agreed to conduct a jailhouse interview with a man accused of murder, she never suspected that her story nearly would land her in the same jail. The man, Sam Bonilla, was co-owner of a martial arts studio in town, worked parttime as a bounty hunter, and had lived in Dodge City for decades. ${ }^{1}$ But Bonilla, a Latino, told O’Brien about long-simmering racial hostilities between certain white residents of Dodge City and the town's swelling population of Latinos, who had flooded into Dodge City to work in the town's meat packing plants. ${ }^{2}$ Bonilla confessed to O’Brien that he had

* Commercial litigation, employment and media lawyer in the Kansas City office of the international law firm Bryan Cave LLP; J.D. 2010, University of Kansas School of Law; B.A. 1998, Journalism and Mass Communication, Drake University. Prior to entering law school, I spent nine years as a newspaper reporter, including stints as the Statehouse bureau chief for the Topeka CapitalJournal and as a Statehouse correspondent for the Harris group of newspapers. I prepared a draft of this Article in connection with the University of Kansas School of Law's Media Law Clinic, headed by Professor M.A. (Mike) Kautsch. I would like to thank Professor Kautsch for his encouragement and support with this Article, both during and after law school, and in particular for helping to see this Article through to publication. I also would like to thank my law firm for allowing time for me to work on this Article, the staff members of the University of Kansas Law Review for their work in editing it, and my wife, Esther, and kids, Sam and Maddie, for putting up with yet a few more hours dedicated to the University of Kansas Law Review.

1. Telephone Interview with Claire O’Brien, Former Reporter, Dodge City Daily Globe (Feb. 25, 2010) [hereinafter O'Brien Interview] (notes on file with author); see Claire O'Brien, Arkansas Riverbed Shooter Claims Self-Defense, DODGE CITY DAILY GlOBE, Oct. 13, 2009, http://www.dodgeglobe.com/news/x593082664/Arkansas-Riverbed-shooter-claims-self-defense.

2. O’Brien Interview, supra note 1; see A.G. Sulzberger, Hispanics Reviving Faded Towns on the Plains, N.Y. TIMEs, Nov. 13, 2011, at A1 ("In the sparsely populated western half of Kansas, every county but one experienced a decline in the non-Hispanic white population, two-thirds of them by more than 10 percent. At the same time, a vast majority experienced double-digit growth in Hispanic population, more than offsetting the declines in seven counties and many smaller cities and towns. Those places with the highest percentage of Hispanic residents tend to have the lowest average ages, the highest birth rates and the most stable school populations.”). 
shot two men —one fatally. ${ }^{3}$ He insisted he had acted in self-defense and went on to tell O'Brien a story about white supremacists who were mad at him and who had access to a cache of guns. ${ }^{4}$

To be sure, the story contained explosive allegations. O'Brien sought corroboration of Bonilla's claims about white supremacists and weapons. ${ }^{5}$ Her reporting led her to a man who claimed to have first-hand knowledge that backed up Bonilla's claims. ${ }^{6}$ Out of fear for his own safety, the man told O'Brien she could use the information he suppliedbut not his name. ${ }^{7}$ O'Brien pledged that she would protect his identity. ${ }^{8}$

O'Brien did not foresee the fallout. During the next several months, Ford County prosecutor Terry Malone subpoenaed O'Brien, seeking the name of her confidential source and all of her notes. ${ }^{9}$ With the backing of her newspaper and its corporate owners, GateHouse Media, Inc., O'Brien fought back. ${ }^{10}$ Before it was over, the case worked its way, briefly, to the Kansas Supreme Court. ${ }^{11}$ And, prompted almost exclusively by the events that unfolded in Dodge City, the Kansas Legislature ultimately passed a statutory reporter's shield law after years of failed attempts. ${ }^{12}$

But along the way, emotions ran hot. O'Brien skipped a court hearing, stating she could no longer trust her newspaper's attorney. ${ }^{13} \mathrm{~A}$ Ford County judge briefly held O’Brien in contempt of court. ${ }^{14}$ O’Brien

3. See O’Brien, supra note 1 .

4. See O’Brien Interview, supra note 1.

5. Id.

6. O’Brien Interview, supra note 1.

7. Id.

8. See id.

9. Petition for Writ of Mandamus and Emergency Order Staying Enforcement of the Inquisition Subpoena to Claire O’Brien Set for a Hearing on January 20, 2010 at Ex. B, GateHouse Media Kan. Holdings II, Inc. v. Love, No. 103,669 (Kan. Jan. 19, 2010) [hereinafter Petition for Writ of Mandamus].

10. See id. at $4-5$.

11. Roxana Hegeman, Dodge Paper Fires Subpoenaed Reporter, Wichita EAGLE, Mar. 9, 2010, http://www.kansas.com/2010/03/09/1216514/dodge-paper-fires-subpoenaed-reporter.html.

12. Act of Apr. 15, 2010 Kan. Sess. Laws 926 (codified as KAN. STAT. AnN. §§ 60-480 to -485 (Supp. 2011)); Tim Carpenter, Reporter Shield Advances, TOPEKA CAPITAL-J., Mar. 18, 2010, http://cjonline.com/news/legislature/2010-03-18/reporter_shield_advances.

13. James Carlson, Reporter Didn't Testify; Faces Fine, TOPEKA CAPITAL-J., Feb. 10, 2010, http://cjonline.com/news/state/2010-02-10/reporter_didnt_testify_faces_fine.

14. Id. 
became embroiled in a bitter dispute with her newspaper. ${ }^{15}$ And, in the end, O’Brien was fired. ${ }^{16}$

The case also highlighted the confusion surrounding the status of the law in Kansas concerning a constitutional right to a so-called "reporter's privilege" not to testify in court under certain circumstances. "The whole mess could have been avoided if Kansas had a shield law," O'Brien stated in an interview. ${ }^{17}$

Statutory media shield laws, which now exist in forty states and the District of Columbia, offer some protection for subpoenaed journalists. ${ }^{18}$ The protection offered by most shield laws can be overcome by litigants under the proper circumstances, following a balancing of the competing interests of prosecutors, criminal defendants, or civil litigators against the interests of a free press and its ability to gather the news. ${ }^{19}$ The laws are designed with three general goals in mind. First, they help promote the free flow of information by ensuring a measure of protection for sources who otherwise would not come forward because of a fear that their identity could be obtained in court. ${ }^{20}$ Second, they help maintain the media's credibility and independence. ${ }^{21}$ Third, they provide some limitation on the burdensome chore of fighting subpoenas, which takes time, energy, and money away from journalists' primary mission of gathering and disseminating the news. ${ }^{22}$

Even without a statutory shield law, a limited reporter's privilege arises from the common law precedent based on the First Amendment. In 1972, the United States Supreme Court decided Branzburg v. Hayes, a landmark consolidated case involving an attempt to force three reporters to divulge confidential sources and information to a grand jury. ${ }^{23}$ The case divided the Court, resulting in an effective plurality, two separate dissents, and an important concurring opinion that has set the tone for both numerous lower court decisions and a framework for state laws that

15. Id.

16. Hegeman, supra note 11.

17. O’Brien Interview, supra note 1.

18. Aaron Mackey, Number of States with Shield Law Climbs to 40, News Media \& L., Summer 2011, at 27, 27.

19. Leita Walker, Comment, Saving the Shield with Silkwood: A Compromise to Protect Journalists, Their Sources, and the Public, 53 U. KAN. L. REV. 1215, 1222-24 (2005).

20. Id. at $1218-19$.

21. Id. at $1219-20$.

22. Id. at 1220 .

23. 408 U.S. 665, 667-79 (1972). 
provide reporters with some protection from subpoenas. ${ }^{24}$ The Kansas Supreme Court considered the issue once, in a 1978 case in which the Court recognized at least a limited reporter's privilege. ${ }^{25}$

One could argue that a statutory shield law in Kansas would provide clarity and guidance to judges who are faced with balancing-in some cases - the interests of the First Amendment right to a free press against a criminal defendant's Sixth Amendment right to a fair trial. ${ }^{26}$ The Dodge City case offered an opportunity for the Kansas Supreme Court to definitively spell out precisely how the Kansas reporter's privilege should be applied, but the Court declined to get involved. ${ }^{27}$

Longtime media attorney Mike Merriam — who had one conversation with O’Brien in his capacity as the Kansas Press Association's media hotline representative-expressed "surprise[] that the [Kansas] Supreme Court did not at least require [the district court judge] to make the analysis rather than just skip to a conclusion." ${ }^{28}$ Merriam conceded that the judge "probably would have come to the same conclusion ... [but] should have at least held a hearing and followed the law."29

This Article will discuss the Dodge City case and the new Kansas shield law in detail. The Article is laid out in four parts. After this introduction, Part II discusses the background of the Dodge City case, including first-person interviews with more than a dozen of the participants, excerpts from briefs filed, and key holdings from case law precedents that were cited in the case. ${ }^{30}$ Part II goes on to outline the legislative history and the ultimate passage of a media shield law in Kansas. ${ }^{31}$ This Part includes a brief look at the lone case to apply the Kansas media shield law. ${ }^{32}$ In Part III, this Article first contends that

24. See generally id. at 667-709; id. at 709-10 (Powell, J., concurring); id. at 711-25 (Douglas, J., dissenting); id. at 725-52 (Stewart, J., dissenting). While Justice Powell joined the Court's opinion written by Justice White, the position outlined in his concurrence led some commentators to treat Branzburg like a plurality opinion. See Rodney A. Smolla, The First Amendment, Journalists, and Sources: A Curious Study in "Reverse Federalism", 29 CARDOZO L. REV. 1423, 1424-28 (2008) (discussing the tension between and consequences of the opinions written by Justices White and Powell).

25. State v. Sandstrom (In re Pennington), 581 P.2d 812, 814-15 (Kan. 1978).

26. See, e.g., Walker, supra note 19.

27. See Hegeman, supra note 11.

28. Telephone Interview with Mike Merriam, Attorney (Mar. 12, 2010) [hereinafter Merriam Interview] (notes on file with author).

29. See id.

30. See infra Part II.A-C.

31. See infra Part II.D.

32. See infra Part II.E. 
Ford County District Judge Daniel Love failed to properly analyze the reporter's privilege that already existed under common law before the new shield law was passed. ${ }^{33}$ It then analyzes how the case would have been handled under the newly minted Kansas Shield Law, under which the outcome likely would have been different. ${ }^{34}$ Part IV provides a brief conclusion.

\section{BACKGROUND}

\section{A. O'Brien's Jailhouse Interview and the Newspaper Story that Prompted Controversy}

Claire O’Brien accepted a job as a reporter in Dodge City without ever setting foot in the town. ${ }^{35}$ Before moving to Dodge City, she was laid off from a newspaper in Illinois owned by GateHouse Media, ${ }^{36}$ a large, corporate owner of more than 400 community and advertising publications across the country. ${ }^{37}$ O'Brien said she blasted batches of resumes across the country before landing a telephone interview with the Dodge City Daily Globe, another GateHouse publication. ${ }^{38}$

O’Brien previously had worked for the Las Cruces Sun-News, in Las Cruces, New Mexico, which, like Dodge City, has a large Latino population. ${ }^{39}$ And she had spent time in the Midwest. ${ }^{40}$ She thought she knew what she was getting into. ${ }^{41}$ O'Brien stated that she thought she was familiar with the Midwest, but "southwest Kansas is not the Midwest."42 "It is a profound change—sort of like [living in] a petri dish. It is so concentrated here in Dodge City-[with a population of] less than 30,000 people-but some of the most compelling issues that face America, they seem to be here writ large."43

33. See infra Part III.A.

34. See infra Part III.B.

35. O’Brien Interview, supra note 1.

36. Id.

37. About GateHouse Media, GAtEHouse MEdiA, http://www.gatehousemedia.com/about (last visited Apr. 7, 2012).

38. O’Brien Interview, supra note 1.

39. Id.

40. Id.

41. Id.

42. Id.

43. Id. 
Hired as a features and education reporter, O’Brien made a name for herself in the Latino community in Dodge City after she tackled some stories that she said had not been written about prior to her arrival at the newspaper. ${ }^{44}$ For example, she believed that she gained the trust of some of the Latinos in town after she wrote about the shooting death of an undocumented Mexican immigrant. ${ }^{45}$ Another one of her stories discussed a promising young Latino college graduate with plans to go to law school who was felled by violence. ${ }^{46}$ It quickly became apparent to many that O’Brien was not the typical Dodge City resident. ${ }^{47}$

"[I am] fifty-four years old. I spent most of my youth in San Francisco. [I am] a lesbian. And [I am] practically an anarchist," O’Brien explained in an interview. ${ }^{48}$ "I just [do not] fit in at all here. ... [I am] sort of out of context here. Having a more left-of-center approach would not seem so out of place where I come from." ${ }^{49}$ O'Brien conceded that she may have been the perfect vehicle for highlighting the lack of a statutory reporter's shield law in Kansas:

On the other hand, maybe it took a lesbian activist from San Francisco to come out here and fight. Quite a few reporters here have told me [they have] been subpoenaed, but they talked. ... [I have] shown my courage. [I am] a middle-aged lady with two artificial knees. All these kids, these young reporters, they [did not] have the courage to go [to jail]. ${ }^{50}$

The story that sparked O'Brien's First Amendment controversy involved the shooting of two white men - one fatally-and the arrest of a longtime Dodge City Latino resident, Sam Bonilla. ${ }^{51}$ One of O’Brien’s sources in Dodge City, a bail bondsman named Rebecca Escalante, called O'Brien and explained that Bonilla wanted to share his version of events. $^{52}$ Escalante claimed that Bonilla trusted only O'Brien to report the story. ${ }^{53}$ O’Brien explained: "That is the only reason the government
44. Id.
45. Id.
46. Id.
47. See id.
48. Id.
49. Id.
50. Id.
51. Id.
52. Id.
53. Id. 
and crime reporter did not do the story."54 The Latino community had noticed a few of O'Brien's stories-“enough that they thought they would get fairer coverage with [O'Brien] than with the crime reporter." 55

Escorted by Escalante, jail personnel ushered O'Brien into the jail to meet with Bonilla. ${ }^{56}$ Escalante introduced Bonilla to O’Brien and then left. ${ }^{57}$ O’Brien began by telling Bonilla about some of the stories she had written about Latinos. ${ }^{58}$ Then Bonilla started talking-and continued to do so for about an hour and a half, until a guard said it was time for O’Brien to leave. " "He just told me his story," O'Brien recalled. ${ }^{60}$ "I was leaning toward believing him, but I had absolutely not formed any kind of opinion. But he had a right to tell his story."

In the article, O’Brien wrote that Bonilla was accompanied by two children in the Arkansas River bed on Labor Day when two men in a pickup drove aggressively toward them. ${ }^{62}$ He said he carried his gun with him-legally - because he had previously seen wild dogs in the area. $^{63}$ During the jailhouse interview, O’Brien later wrote in her story, "Bonilla had difficulty keeping back tears as he insisted that he had acted in self-defense, stating that [the two men who were shot, Steven] Holt and [Tanner] Brunson[,] had attempted to run him down in their pickup just before getting out of the truck and advancing on him and the two children he acted to protect." 64

In what proved to be the most controversial part of the story, O'Brien wrote that Escalante had declined to bail Bonilla out of jail because she was "concerned for his safety" and that Escalante had "been warned by several people that he will be in danger if he is released." 65 The story went on to report:

A source who is known to the Globe but who did not wish to be publicly identified said Monday that Tanner Brunson, who was
54. Id.
55. Id.
56. Id.
57. Id.
58. Id.
59. Id.
60. Id.
61. Id.
62. Id.; see also O’Brien, supra note 1.
63. O’Brien Interview, supra note 1; see also O’Brien, supra note 1.
64. O’Brien Interview, supra note 1.
65. Id. 
wounded in the shooting, has a base of support that is well-known for its anti-Hispanic beliefs. The same source stated he has seen evidence that Brunson's support base has a supply of semi-automatic weapons. manner. ${ }^{66}$

The source did not characterize Holt or his family in the same

O'Brien included the portion of the story that relied on the anonymous source because she did not want to rely solely on the claims of a man in jail who had been charged with murder. ${ }^{67}$ When O'Brien returned to the newspaper after her interview with Bonilla, she called Escalante to see if she knew anyone who could back up the claims. ${ }^{68}$ Escalante introduced O'Brien to another source-a man who said he had seen the cache of weapons and knew of its connection to a hate group. ${ }^{69}$ O'Brien did not meet the source in person, but rather spoke to him by phone. $^{70}$ Escalante was with the source and listened to the conversation when he talked to O'Brien. ${ }^{71}$ O'Brien trusted the source because she trusted Escalante. ${ }^{72}$ "She introduced [the source], told me how long [she had] known him-years and years-and vouched for him. I considered it to be good enough., 73

The source relayed the reason he had been present on the Brunson family's property, what he had seen, and what he knew as a longtime community member about the family's ties to a white supremacist group called the Aryan Brotherhood. ${ }^{74}$ O'Brien said she chose not to attempt to meet him in person because the source was frightened about talking to the media. ${ }^{75}$ "I figured, what was the point of me doing that when we both knew that I knew who he was?" O'Brien said in an interview. ${ }^{76}$ "[H]e was really afraid. ... I just decided not to scare him further."77 The source told O'Brien that, if she used anything he had told her, she

\footnotetext{
66. O’Brien, supra note 1.

67. O’Brien Interview, supra note 1.

68. Id.

69. Id.

70. Id.

71. Id.

72. Id.

73. Id.

74. Id.

75. Id.

76. Id.

77. Id.
} 
could not print his name. ${ }^{78}$ O’Brien agreed. "I gave him my word. I [did not] realize there [was not] a shield law in Kansas. That was stupid on my part- [there is] a pretty strong one in Illinois. But I gave him my word., 79

Before publishing the story, O'Brien attempted unsuccessfully to reach Holt's sister for comment. ${ }^{80}$ She also called the local Ford County Attorney, Terry J. Malone, to get his comments about the case and his reaction to what Bonilla and the confidential source had claimed. ${ }^{81}$ "[W]hen I asked the prosecutor about it, he just hit the roof: '[that is] not relevant at all,"” O’Brien recalled.

I just took him through the whole interview, waiting for comment, because [I am] a reporter. Of course I want both sides of the story. I want a better story. He started saying things like, "that could really influence a jury." He lectured me that running it would be very irresponsible. ${ }^{82}$

Ultimately, Malone declined to comment to O'Brien about the specific allegations that her story contained. ${ }^{83}$ The story quoted Malone as stating: "We [do not] want to try this case in the press. But we are satisfied that the evidence we will present will prove our case against $\mathrm{Mr}$. Bonilla.",84

In an affidavit accompanying a brief that Malone submitted to the Kansas Supreme Court, Malone wrote that O’Brien told him during their telephone conversation that Bonilla had cursed at Brunson, who was driving the vehicle, as he walked in the riverbed. ${ }^{85}$ Malone also attested in the affidavit that O'Brien told him that "she had learned from sources that Tanner Brunson had ties to the Aryan Brotherhood, a group with anti-[H]ispanic beliefs." ${ }^{86}$ O'Brien strongly denied in an interview that she had ever used the words "Aryan Brotherhood" in her telephone

78. Id.; see also O'Brien, supra note 1 (providing information about Brunson from a source "who did not wish to be publicly identified").

79. O’Brien Interview, supra note 1.

80. O’Brien, supra note 1.

81. O’Brien Interview, supra note 1.

82. Id.

83. O’Brien, supra note 1.

84. Id.

85. Affidavit of Ford County Attorney at 2, GateHouse Media Kansas Holdings II, Inc. v. Love, No. 103,669 (Kan. Jan. 19, 2010).

86. Id. 
conversation with Malone. ${ }^{87}$

\section{B. Procedural History}

\section{Malone Subpoenas O’Brien}

Two weeks after O’Brien's story appeared in print, Malone filed two subpoenas in Ford County District Court. ${ }^{88}$ The first sought O’Brien's testimony in a proceeding known by the medieval-sounding title "inquisition." 89 An inquisition is a rare procedure in Kansas, ${ }^{90}$ and it allows a prosecutor to subpoena witnesses to testify if the prosecutor "has knowledge of any alleged violation of the laws of Kansas." 91 The second subpoena ordered O'Brien to produce her notes from the jailhouse interview with Bonilla. ${ }^{92}$

In an interview months later, Malone conceded that he never imagined that the two subpoenas would lead to a court battle that would cost GateHouse more than $\$ 50,000$ in legal fees. ${ }^{93}$ From his perspective, he had a criminal defendant making statements to a reporter while he was still in jail. ${ }^{94}$ There was no question in Malone's mind that Bonilla's statements were relevant to the prosecution. ${ }^{95}$ Further, the story contained allegations that a member of the community-the criminal defendant Sam Bonilla—was in danger. ${ }^{96}$ Malone initially believed O'Brien might turn the notes over voluntarily. ${ }^{97}$ After all, Malone reasoned, Bonilla had requested the interview and wanted his comments to be printed, so surely he would not object to the prosecutor having access to his entire version of events. ${ }^{98}$ As for the confidential source, O'Brien had printed that Bonilla was in danger, and Malone thought most reporters would cooperate with authorities if they possessed such

87. O’Brien Interview, supra note 1.

88. Petition for Writ of Mandamus, supra note 9, at Ex. B.

89. Id.

90. Merriam Interview, supra note 28.

91. KAN. StAT. ANN. § 22-3101(1) (2007).

92. Petition for Writ of Mandamus, supra note 9, at Ex. B.

93. Telephone Interview with Terry Malone, Ford Cty. Attorney (April 16, 2010) [hereinafter Malone Interview] (notes on file with author).

94. Id.

95. Id.

96. Id.

97. Id.

98. Id. 
serious information. ${ }^{99}$ When O’Brien refused to cooperate voluntarily, Malone reviewed case law regarding a common law reporter's privilege in Kansas and determined the analysis was an easy one--the information O’Brien had was relevant, and the prosecutor needed it. ${ }^{100}$

Malone explained his initial intentions:

I knew Claire for a couple months [prior to subpoenaing her] and [did not] consider her an enemy—and I [did not] consider myself an enemy of the press.... But I thought the information Mr. Bonilla gave to her might be relevant to our prosecution. But really, the big thing was, right there on the front page of our local newspaper was the fact that we had a guy that was alleged to be in serious harm should he ever be outside the custody of our sheriff. [That is] hard to ignore as a county prosecutor. People are saying, "We have information someone wants to do harm to someone in our community." That really drove the inquisition as much as anything. We have a duty to protect people and we had to do what we could to see if this threat was real or just imagined. ${ }^{101}$

Malone dismissed any suggestion that he was on a "fishing expedition." "102 He said journalists "should be protected from fishing expeditions. That [was not] what we were doing. We [were not] fishing."

\section{The Dodge City Daily Globe’s Motion to Quash}

\section{a. Legal Strategy}

Within days, attorneys representing GateHouse responded in Ford County District Court with a motion to quash the subpoena. William A. Hurst, a partner in the Albany, New York, office of Hiscock \& Barclay, LLP, is national counsel for GateHouse. ${ }^{104}$ Hurst filed a brief within forty-eight hours of learning about the case for the first time. ${ }^{105}$ Hurst quickly learned that the inquisition was not commonly used in Kansas. ${ }^{106}$

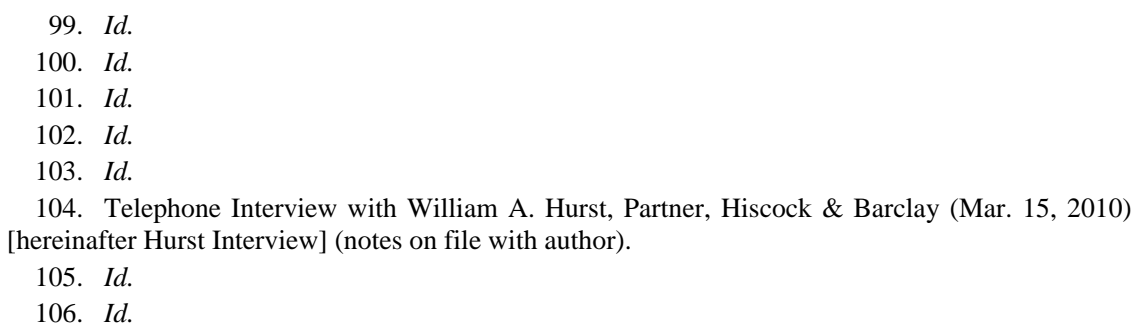


He also realized that using the inquisition procedure meant that the prosecutor's investigation into O’Brien's jailhouse interview was "not tied directly to the underlying criminal case."107 According to Hurst, "the first red flag that goes up is 'fishing expedition.,",108

When Hurst learned that Kansas had no shield law-he said he was unaware at that early date that such a proposal was "kicking around the Legislature"109_and that the last time the Kansas Supreme Court had examined the reporter's privilege was more than thirty years prior in In re Pennington, ${ }^{110}$ he sensed this case would be an opportunity to define such a privilege. ${ }^{111}$ "We felt like we had a pretty clean slate to be writing on. In the interim [since In re Pennington, there had been] some good Tenth Circuit precedent .... A And [In re Pennington] is really not very clear. ... [It is] hard really to pin down the Kansas Supreme Court on what it is [they are] doing." 112

\section{b. Precedents}

Indeed, much of the case law in the area of the reporter's privilege is less than crystal clear. ${ }^{113}$ Although Hurst wove together numerous cases offering persuasive authority from other jurisdictions, Hurst relied primarily on three cases to support his motion to quash the subpoenas.

\section{i. Branzburg v. Hayes}

Considered the seminal case on a reporter's privilege, the 1972 United States Supreme Court case of Branzburg v. Hayes consolidated four cases involving three reporters who had refused to disclose the names of confidential sources and unpublished information. ${ }^{114}$ The Court held that requiring reporters to testify before grand juries does not violate their First Amendment rights. ${ }^{115}$

An important concurring opinion from Justice Powell, however,

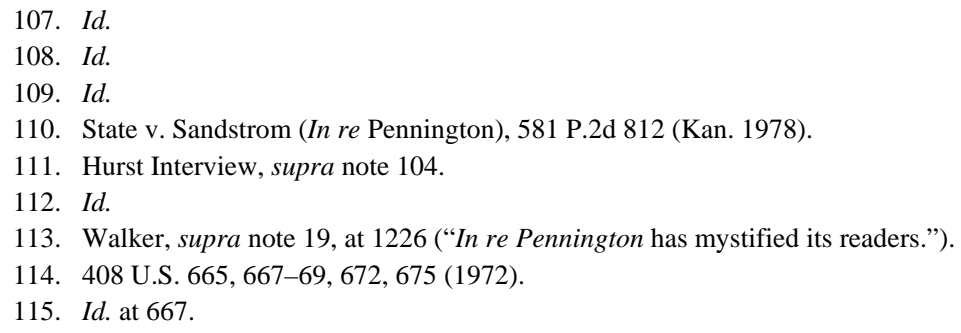


softened the one-size-fits-all tone of the Court's holding. ${ }^{116}$ Justice Powell, casting the fifth vote in a 5-4 decision, responded directly to a forceful and lengthy dissent written by Justice Stewart. ${ }^{117}$ Justice Powell expressly rejected Justice Stewart's contention that the Court had held that "state and federal authorities are free to 'annex' the news media as 'an investigative arm of government.", 118 Justice Powell went on to write:

The asserted claim to privilege should be judged on its facts by the striking of a proper balance between freedom of the press and the obligation of all citizens to give relevant testimony with respect to criminal conduct. The balance of these vital constitutional and societal interests on a case-by-case basis accords with the tried and traditional way of adjudicating such questions. ${ }^{119}$

And in a footnote in his short concurrence, Justice Powell further stated that "the court-when called upon to protect a newsman from improper or prejudicial questioning-would be free to balance the competing interests on their merits in the particular case."

\section{ii. State v. Sandstrom (In re Pennington)}

Relying heavily on Justice Powell's concurrence, which was required to prop up the Court's 5-4 holding, the Kansas Supreme Court has visited the issue of a reporter's privilege a single time, in a 1978 case known as In re Pennington. ${ }^{121}$ In that case, the court considered whether a news reporter may exercise a constitutional testimonial privilege to protect the identity of a confidential news source. ${ }^{122}$ The court held that "a newsperson has a limited privilege of confidentiality of information and identity of news sources, although such does not exist by statute or common law."123 Further, the court noted that "[t]he United States Supreme Court recognized the privilege in Branzburg v. Hayes." "124

\footnotetext{
116. Id. at 709 (Powell, J., concurring) (noting that he wrote separately to "emphasize ... the limited nature of the Court's holding”).

117. Compare id. at 709-10, with id. at 725-52 (Stewart, J., dissenting).

118. Id. at 709 (Powell, J., concurring).

119. Id. at 710 .

120. Id. at $710 \mathrm{n.}^{*}$.

121. 581 P.2d 812 (Kan. 1978).

122. Id. at 814 .

123. Id.

124. Id.
} 
Reading Justice Powell's concurrence along with Justice White's opinion, the Kansas Supreme Court held that courts must apply a caseby-case balancing test to determine whether the reporter should be constitutionally entitled to decline to testify. ${ }^{125}$ The court wrote that "[c]ourts applying Branzburg to criminal cases have generally concluded that the proper test for determining the existence of a reporter's privilege in a particular criminal case depends upon a balancing of the need of a defendant for a fair trial against the reporter's need for confidentiality."

[D]isclosure has been required only in those criminal cases where it is shown the information in possession of the news reporter is material to prove an element of the offense, to prove a defense asserted by the defendant, to reduce the classification or gradation of the offense charged, or to mitigate or lessen the sentence imposed. When the information sought has a bearing in one of these areas, the newsperson's privilege must yield to the defendant's rights to due process and a fair trial. ${ }^{127}$

The court also noted that "[w]hile courts recognize that a news reporter's privilege is more tenuous in a criminal proceeding than in a civil case, that fact in and of itself does not automatically require disclosure in a criminal case."128

\section{iii. Silkwood v. Kerr-McGee Corp.}

In the brief five-and-a-half-year span between Branzburg and In re Pennington, the Tenth Circuit also had occasion to visit the issue of the reporter's privilege in 1977 in Silkwood v. Kerr-McGee Corp. ${ }^{129}$ In Silkwood, the court considered whether a documentary film producer was entitled to protect information he had gathered while making a factual investigation for his movie. ${ }^{130}$ The court's decision was important for two reasons. First, it considered whether a reporter's privilege exists. ${ }^{131}$ Second, if one did in fact exist, the court determined whether such a

\footnotetext{
125. Id. at 815 .

126. Id. (gathering cases).

127. Id. (gathering cases).

128. Id.

129. 563 F.2d 433 (10th Cir. 1977).

130. Id. at 434 .

131. Id. at 435 .
} 
privilege should apply to a documentary filmmaker. ${ }^{132}$ After considering Branzburg, the Tenth Circuit concluded that even the majority opinion noted that reporters should not be required "to publish [their] sources of information or indiscriminately to disclose them on request." ${ }^{\text {133 }}$ Based on this statement and Justice Powell's concurrence, the Tenth Circuit concluded that the very existence of the reporter's privilege "is no longer in doubt." 134 The court found that the Branzburg Court, "[i]n holding that a reporter must respond to a subpoena ... [was] merely saying that he must appear and testify. He may, however, claim his privilege in relationship to particular questions which probe his sources."135

The Tenth Circuit went on to adopt a four-part balancing test first developed by the Second Circuit. ${ }^{136}$ The Tenth Circuit found that lower courts could apply this test when confronted with a journalist purporting to exercise a constitutional privilege not to testify regarding confidential sources. ${ }^{137}$ The test would invite a judge to consider four criteria:

(1) "[w]hether the party seeking information has independently attempted to obtain the information elsewhere and has been unsuccessful”;

(2) "[w] hether the information goes to the heart of the matter";

(3) "[w]hether the information is of certain relevance";

(4) “[t]he type of controversy.”,"138

According to one commentator, the Silkwood decision "provides a compromise" for courts faced with litigants arguing in favor of blanket rules_either absolute privilege, or absolute lack of privilege. ${ }^{139}$ The case offers

clear standards for courts to apply when they face a reporter's claim of privilege. Perhaps even more important, given the national state of mind and the rapidly changing face of journalism, Silkwood protects

132. Id.

133. Id. at 437 .

134. Id.

135. Id.

136. Id. at 438 (citing Garland v. Torre, 259 F.2d 545 (2d Cir. 1958)).

137. Id.

138. Id. (citing Garland, 259 F.2d 545).

139. Walker, supra note 19, at 1237. 
against abuse of such a privilege. It does so by providing only a qualified privilege to journalists and by formulating a way to define just who a journalist is. ${ }^{140}$

\section{c. GateHouse's Use of the Precedents in Support of Its Motion to} Quash

Relying on Branzburg, In re Pennington, and Silkwood, as well as persuasive authorities from other jurisdictions, GateHouse argued that "the constitutional reporter's privilege cannot be overcome in this proceeding unless the government demonstrates that the testimony sought pursuant to the subpoena is critical to the prosecution's attempt to determine whether a criminal violation exists and not otherwise available from any other source."141 GateHouse argued that the prosecutor's attempt to compel O'Brien's testimony "substantially interferes with the independence of the press by effectively converting Globe reporter Claire O'Brien from an impartial reporter of the news into an investigative agent for the government" and that it amounted to a "fishing expedition." 142

GateHouse argued that "the Constitution forbids the government from compelling information from journalists without a heightened showing of the need for that information and exhaustion of other sources." $^{\text {"143 }}$ The brief went on to argue that the prosecution failed to meet its burden under the balancing tests set forth under Branzburg, In re Pennington, and Silkwood. In particular, under the framework established by In re Pennington,

disclosure has been required only in those criminal cases where it is shown the information in possession of the news reporters is material to prove an element of the offense, to prove a defense asserted by the defendant, to reduce the classification or gradation of the offense charged, or to mitigate or lessen the sentence imposed. ${ }^{144}$

140. Id. at $1237-38$.

141. The Dodge City Globe's Memorandum of Law in Support of Motion to Quash Subpoena to Non-Party Professional Journalist Claire O’Brien at 1, In re Inquisition to Inquire Into Certain Alleged Violations of the Laws of Kan., No. 09 MR 163 (Kan. Dist. Ct. Nov. 2, 2009).

142. Id. at 2 (quoting Silkwood v. Kerr-McGee Corp., 563 F.2d 433, 438 (10th Cir. 1977)) (internal quotation marks omitted).

143. Id. at 4.

144. Id. at 11 (quoting State v. Sandstrom (In re Pennington), 581 P.2d 812, 815 (Kan. 1978)) (internal quotation marks omitted). 


\section{Malone Responds}

In his response to GateHouse's motion to quash, Ford County Attorney Malone argued that Justice Powell's concurrence "has no precedential value.”145 Rather, the State argued, Justice White's opinion standing alone controls, and under that holding, the First Amendment "did not relieve newspaper reporters of the obligation that all citizens have to respond to a grand jury subpoena and answer questions relevant to a criminal investigation."146

The State strongly emphasized that, particularly in criminal cases, relevance was the key issue-and the information the prosecutor sought, he argued, certainly was relevant. ${ }^{147}$ Further, Malone argued, as the judge in an inquisition would play essentially the same role as a grand jury, "there is not even a requirement that the State make a preliminary showing of relevance or that the information not be available from other sources" because that is the role of the fact-finder to determine. ${ }^{148}$ Finally, even if the judge applied Justice Powell's balancing test, the only concerns specifically articulated by Justice Powell were that "reporters should not be forced to testify about confidential sources if the investigation is in bad faith, is only remotely or tenuously connected to the investigation, or has no legitimate need."149 GateHouse failed to demonstrate the investigation fell into one of those categories, the State contended. $^{150}$

The State went on to argue that the Kansas Supreme Court misconstrued Branzburg in In re Pennington to find a balancing test where there was none. ${ }^{151}$ But even under In re Pennington, particularly in a criminal case where "a news reporter's privilege is more tenuous ... than in a civil case,... [t]he proper test enunciated by the Branzburg majority is whether the information sought is relevant to the issues before the tribunal." ${ }^{\text {"152 }}$ Thus, the State concluded, the appropriate test

\footnotetext{
145. State's Response to Witness/Movant's Motion to Quash Subpoena to Non-Party Professional Journalist Claire O’Brien at 7, In re Inquisition to Inquire Into Certain Alleged Violations of the Laws of Kan., No. 09 MR 163 (Kan. Dist. Ct. Nov. 17, 2009) [hereinafter State's Response to Motion to Quash Subpoena].

146. Id. at 3 (citing Branzburg v. Hayes, 408 U.S. 665, 665 (1972)).

147. Id. at 17.

148. Id. at 6 .

149. Id. at 7.

150. Id.

151. Id. at 8 .

152. Id. at 8-9 (quoting State v. Sandstrom (In re Pennington), 581 P.2d 812, 815 (Kan. 1978))
} 
adopted by the Kansas Supreme Court for the circumstances surrounding 
the O'Brien subpoena was "one of relevance, and not of further balancing of the sort contemplated in other jurisdictions."153

Finally, the State pointed out that the Tenth Circuit decided the Silkwood case before the In re Pennington decision. ${ }^{154}$ Therefore, if the Kansas Supreme Court wanted to adopt the sort of four-part balancing test articulated in the Silkwood decision, it could have-but the court chose not to do so. ${ }^{155}$ In conclusion, the State argued, "[t]he proper test . . . is whether the information sought is relevant.",156

\section{GateHouse Replies}

In response to the State's brief, GateHouse challenged the State's interpretation of both Branzburg and In re Pennington. ${ }^{157}$ GateHouse argued that Justice Powell's concurring opinion in Branzburg was "pivotal" as it was the "deciding vote" to create a majority. ${ }^{158}$ Further, GateHouse argued that "[t]he government's position here rests on a fundamental misapplication of the holding of the controlling decision of the Kansas Supreme Court, and advocates a legal standard-one of mere relevancy-which would basically extinguish the efficacy of the qualified reporter's privilege."159 GateHouse reiterated that, under In re Pennington, the proper approach was to balance the needs of the prosecutor against the freedom of the press. ${ }^{160}$ And under the circumstances of this case, GateHouse argued, the government came up short because

while the information sought by the subpoenas may be relevant in the broadest sense, the government cannot establish that it has exhausted all alternative sources for the same information, and [it] has failed to show that the information is material or necessary to prove its case against Bonilla, or to identify the commission of any other crime. ${ }^{161}$

\footnotetext{
153. Id. at 9 .

154. Id. at 10

155. Id.

156. Id. at 17 (quoting In re Pennington, 581 P.2d at 815).

157. The Dodge City Daily Globe's Reply Brief in Further Support of Motion to Quash Subpoena to Non-Party Professional Journalist Claire O’Brien at 1, In re Inquisition to Inquire Into Certain Alleged Violations of the Laws of Kan., No. 09 MR 163 (Kan. Dist. Ct. Nov. 25, 2009).

158. Id. at 5.

159. Id. at 1.

160. Id. at 9.

161. Id. at 12 .
} 


\section{Judge Love Rules}

In a five-page order issued on December 9, 2009, Ford County District Court Judge Daniel L. Love declined to quash the subpoenas and instead ordered the inquisition to proceed. ${ }^{162}$ Judge Love concluded that the Kansas Supreme Court had held that "a newsperson has a limited privilege of confidentiality of information and identity of news sources, although such does not exist by statute or common law." 163 The privilege, Judge Love noted, "is more tenuous in a criminal proceeding than in a civil case." 164 Thus, Judge Love concluded, "[t]he proper test enunciated by the Branzburg majority is whether the information sought is relevant to the issues before the tribunal." 165

Just to be safe, Judge Love purported to reach his conclusion under both a relevancy standard and a balancing test. ${ }^{166}$ With little in the way of analysis, Judge Love wrote that even "when applying the balancing test, it is clear to the Court that the need for this information outweighs the news reporter's privilege of confidentiality." ${ }^{67}$ He went on to find that "the [In re Pennington] and Branzburg cases involve criminal charges and indicate the information held by the news reporter only must be relevant to be discovered in a criminal case." ${ }^{68}$ Thus, "[u]nder either analysis, the information must be divulged." 169

"What Judge Love did was kind of clever in some respects," Hurst said in an interview months later. ${ }^{170}$ "Really, [he] modeled his opinion after In re Pennington—including its ambiguity."171

\footnotetext{
162. In re Inquisition to Inquire Into Certain Alleged Violations of the Laws of Kan., No. 09 MR 163, at 5 (Kan. Dist. Ct. Dec. 9, 2009).

163. Id. at 2 (quoting State v. Sandstrom (In re Pennington), 581 P.2d 812, 814 (Kan. 1978)) (internal quotation marks omitted).

164. Id. at 3 (quoting In re Pennington, 581 P.2d at 815) (internal quotation marks omitted).

165. Id. at 3 (emphasis omitted) (quoting In re Pennington, 581 P.2d at 815) (internal quotation marks omitted).

166. Id. at 4-5.

167. Id. at 4.

168. Id. (emphasis omitted).

169. Id. at 5.

170. Hurst Interview, supra note 104.

171. Id.
} 


\section{Mandamus Action Before the Kansas Supreme Court}

\section{a. An Unwelcome Surprise}

GateHouse immediately sought to stay Judge Love's ruling as part of an interlocutory appeal in the form of a mandamus action filed with the Kansas Supreme Court. Just weeks before the supreme court ruled, however, there was yet another surprise about the confidential source at the heart of the inquisition. According to O'Brien, she found out in December that her source had lied to her about his last name. ${ }^{172}$ Although the newspaper had reported that the confidential source was "known to the Globe," 173 it turned out he had lied to O’Brien about his identity-damaging not only his own credibility as a source but also that of O'Brien and her newspaper. ${ }^{174}$ Darrel Adams, the publisher of the Dodge City Daily Globe, admitted he was not pleased to learn the newspaper had been hoodwinked by the confidential source. ${ }^{175}$ "[T]he source was identified to us at the twenty-fourth hour," Adams said in an interview. ${ }^{176}$ "At that point in time, we were very embarrassed.",177

O’Brien, however, did know the confidential source's true first name, place of employment, and job title. ${ }^{178}$ She also knew that her trusted source, the bail bondsman Escalante, personally knew the confidential source. ${ }^{179}$ "I thought, if someone asks me, 'Do you know his name?' I would say no. But 'Do you know who he is?' I would say, 'Yes,"” O’Brien recalled. ${ }^{180}$ "[There are] just not that many people who do his job. If I said his first name and what he did, [he is] absolutely identified." 181

Gene Lehmann's first day as the managing editor of the Globe was O’Brien's first day in court after being subpoenaed. ${ }^{182}$ He found that his

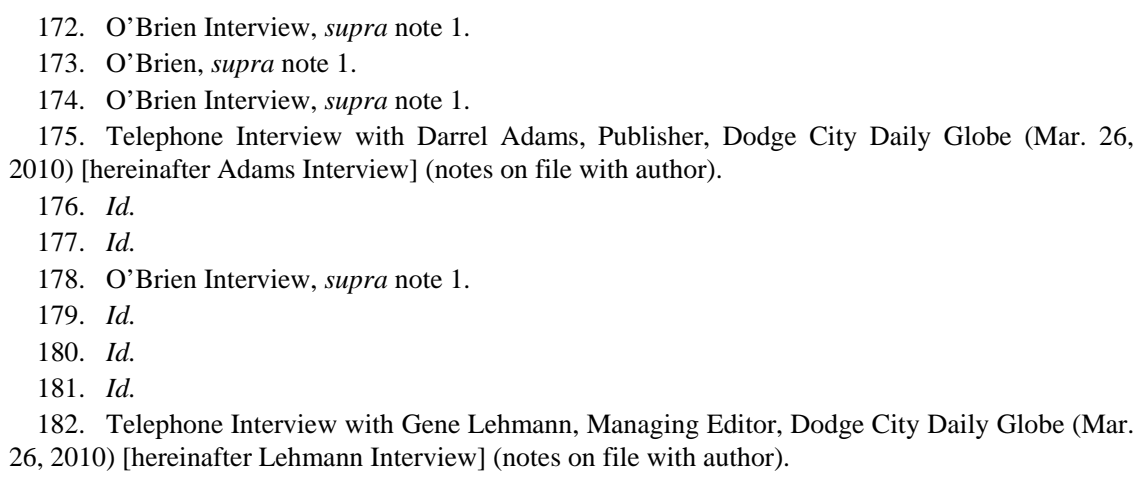


late arrival to the situation gave him some distance to evaluate the big picture. ${ }^{183}$ Lehmann discovered that O'Brien did not follow the newspaper's policies surrounding the use of unnamed sources, and her failure to follow policy was not identified by anyone else at the newspaper in any of the steps leading up to publication of her story. ${ }^{184}$ "The bottom line on all this is that Claire had no idea what her source's name was," Lehmann said, adding that she should have been "quizzed" about how well she knew him and how she could trust him. ${ }^{185}$ "She knew how to find him, but she did not have his real name. Had I been here when the story was written — and [hindsight is] 20/20 — but had I been here and had I quizzed her, it would have never been published."186

Adams, the Globe's publisher, agreed that newspaper protocol was not followed in the use of O'Brien's confidential source. ${ }^{187}$ There should have been at least two sources, not one, Adams conceded. ${ }^{188}$ And the publisher or a senior editor should have been involved in deciding whether to publish the comments of an unnamed source. ${ }^{189}$

"[If] we had it to do over again, we probably [would not] have done it, quite honestly,” Adams said of publishing O’Brien's story. ${ }^{190}$

We would have tried to get sources on the record .... We would have had to have better sources, quite honestly.... If it comes up again, [we are] going to have to have better sources. [We are] going to have to be able to better verify those sources. [We will] still stand behind our reporters, of course.... But our sources are going to have to be very, very accurate, and [we are] going to have to do a better job as a management team of verifying those sources. ${ }^{191}$

O'Brien acknowledged that when she learned her source had lied to her about his name, she was furious and briefly considered revealing his identity to authorities at that point. ${ }^{192}$ "I was growing weary, and I was mad at him," O’Brien recalled of the court battle that stretched for

\footnotetext{
183. Id.

184. Id.

185. Id.

186. Id.

187. Adams Interview, supra note 175.

188. Id.

189. Id.

190. Id.

191. O’Brien Interview, supra note 1.

192. Id.
} 
months; she decided to stand her ground: "But in the end, I promised him. I had to keep my word."

\section{b. GateHouse’s Petition for Mandamus}

Notwithstanding the embarrassment over the source's name, the newspaper pressed forward with its request for reversal of the trial court by the Kansas Supreme Court. GateHouse argued that Judge Love had "misconstrued the holding of the Kansas Supreme Court in In re Pennington and ignored other applicable authority" in reaching his conclusion that information known by a reporter merely must be relevant to warrant compelled disclosure. ${ }^{194}$ GateHouse went on to reiterate that In re Pennington calls for a balancing test of the sort described in Silkwood and that the government in O'Brien's case had failed to meet such a test. ${ }^{195}$ GateHouse warned that "by substituting... a mere relevancy standard, the District Court's ruling here threatens to eviscerate the constitutional reporter's privilege as it has existed in the State of Kansas” since 1978. ${ }^{196}$

\section{c. The Attorney General's Response on Behalf of Judge Love}

Because he was named as the defendant of the mandamus action, Judge Love, through his counsel, Assistant Kansas Attorney General Stephen Phillips, filed a brief in the case that was "largely limited to procedural issues." 197 Phillips indicated that Love's "decisions and the reasons therefore are expressed in the record.”198 After recapping Judge Love's rationale, Phillips also emphasized that the determination of whether to compel a reporter's testimony was "a discretionary decision" and that the "extraordinary" mandamus relief sought by GateHouse was inappropriate. ${ }^{199}$

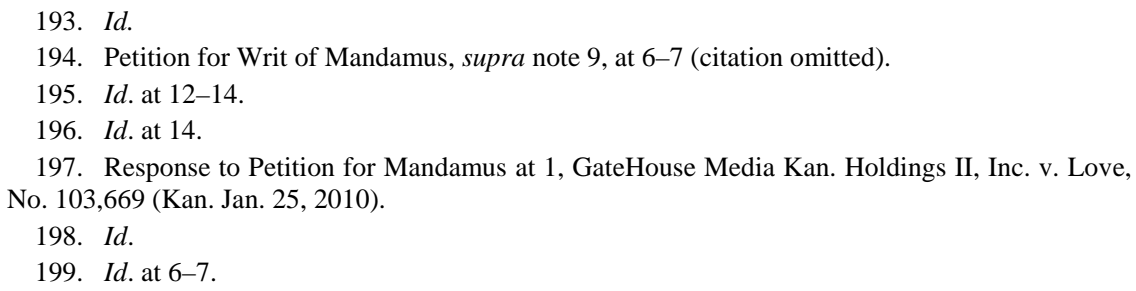




\section{d. Malone’s Response}

Terry Malone, the Ford County Attorney, also argued in his brief that Judge Love's ruling was not sufficiently extraordinary to require the Kansas Supreme Court's intervention. ${ }^{200}$ Malone argued that the Kansas Supreme Court should not enjoin him from moving forward with his inquisition. ${ }^{201}$ In his forty-four-page brief, Malone reiterated his arguments that Branzburg created no reporter's privilege that would exempt journalists "from responding to subpoenas or answering questions relevant to a criminal investigation." 202 And under In re Pennington, Malone argued, the proper test is "whether the information sought is relevant to the issues before the tribunal."203

\section{e. The Kansas Supreme Court Rules}

With more than 150 pages of motions, briefs and exhibits before iton top of an application to submit an amicus brief filed by the American Civil Liberties Union of Kansas and Western Missouri ${ }^{204}$ - the Kansas Supreme Court's decision was remarkable only for its brevity. In a twosentence order on Feb. 2, 2010, the Kansas Supreme Court essentially declined to get involved. ${ }^{205}$ The Order, signed by Chief Justice Robert E. Davis, stated simply: "The petition for writ of mandamus filed in the above-captioned case on January 19, 2010, is denied on current showing. Further, all motions requesting permission to file amicus briefs in the case are denied as moot.”206

The media portrayed the Kansas Supreme Court's decision as a ruling on the merits compelling O’Brien to testify. ${ }^{207}$ Ron Keefover, the

200. State’s Response to Petitioners' Request for Emergency Order to Stay Inquisition Subpoena to Claire O’Brien Previously Set for Hearing on January 20, 2010 at 2-4, GateHouse Media Kan. Holdings II, Inc. v. Love, No. 103,669 (Kan. Jan. 25, 2010) [hereinafter State’s Response to Emergency Stay Request].

201. Id.

202. Id. at 10 .

203. Id. at 19 (quoting State v. Sandstrom (In re Pennington), 581 P.2d 812, 815 (Kan .1978)) (internal quotation marks omitted).

204. Motion for Permission to File Amicus Brief, GateHouse Media Kan. Holdings II, Inc. v. Love, No. 103,669 (Kan. 2010).

205. Order, GateHouse Media Kan. Holdings II, Inc. v. Love, No. 103,669 (Kan. 2010).

206. Id.

207. See, e.g., Cristina Abello, Kansas High Court Allows Reporter Subpoena to Stand, REPS. COMMITTEE FOR FREEDOM OF THE PRESS (Feb. 3, 2010), http://www.rcfp.org/browse-media-lawresources/news/kansas-high-court-allows-reporter-subpoena-stand ("The Kansas Supreme Court 
Kansas Supreme Court's official spokesman, indicated that it would be wrong to infer that the Court had ruled on the merits of the case. ${ }^{208}$ "The merits of the matter were not resolved [because] [i]t was not a ruling on the merits," he explained. ${ }^{209}$ Although Keefover cautioned he could only "speculate" about the court's motives, the fact that the court wrote that the petition for mandamus was denied "on current showing"210 indicated to him that the case perhaps was not ripe for a decision. ${ }^{211}$ O'Brien, after all, had not yet been held in contempt of court, he noted. ${ }^{212}$

Malone said the Kansas Supreme Court seemed to echo what he believed was a "clear cut" case-one Judge Love also handled easilywhen he noted. ${ }^{213}$

The issues that were brought up by GateHouse Media on [O'Brien's] behalf, most of them were not on point. They talked about a lot of civil cases that really were not that germane to the issues at hand. So even though there may have been a big brief filed by a New York law firm, it really boiled down to not being relevant to our case. ${ }^{214}$

Hurst, however, was stunned that the supreme court declined to get involved. ${ }^{215}$ As he recalled, "There was a lot of publicity around the case. A lot of people were looking at it for a lot of reasons. We thought,

yesterday ruled that prosecutors may force Dodge City Globe reporter Claire O’Brien to testify about her news gathering activities and materials in a murder trial.” (emphasis added)); James Carlson, Globe Reporter Faces Deadline, TOPEKA CAPITAL-J., Feb. 10, 2010, http://cjonline.com/ news/state/2010-02-09/globe_reporter_faces_deadline (noting that the Kansas Supreme Court "refused the Globe's effort to quash the subpoena, in effect ordering O'Brien to testify" (emphasis added)); Editorial: Kansas Supreme Court's Action Will Have Chilling Effect, WeLLINGTON DAILY NEws (Feb. 3, 2010), http://www.wellingtondailynews.com/news/state/x1090836612/EditorialKansas-Supreme-Courts-action-will-have-chilling-effect ("Kansas Supreme Court Chief Justice Robert Davis denied the petition in only 37 words—one paragraph. The court refused to even hear arguments or receive briefs in the case. It is obvious that the court was afraid the facts might interfere with the court's predisposed ruling."); Russ Morgan, Governor Signs Shield Law, EMPORIA GAZETTE, April 16, 2010, http://www.emporiagazette.com/news/2010/apr/16/governor-signs-shieldlaw/ (“[T]he Kansas Supreme Court took up the case, ruling against her.”).

208. Telephone Interview with Ron Keefover, Educ./Info. Officer, Kan. Judicial Branch (Mar. 26, 2010) [hereinafter Keefover Interview] (notes on file with author).

209. Id.

210. Order, supra note 205.

211. Keefover Interview, supra note 208.

212. Id.

213. Malone Interview, supra note 93.

214. Id.

215. Hurst Interview, supra note 104. 
'[It has] been thirty years since [the State of Kansas] dealt with it.' . . . I was very surprised by the cursory rejection ....,216

\section{Post-Supreme Court Fallout}

\section{O’Brien Clashes with GateHouse and Its Attorney}

Following the Kansas Supreme Court's decision not to get involved, the case took a dramatic turn after O'Brien and her newspaper's corporate owners and attorneys became involved in a dispute. ${ }^{217}$ Hurst viewed the Kansas Supreme Court's ruling as the end of the line for the company's legal battle, which up until that point had perfectly mirrored the position of O’Brien. ${ }^{218}$

From the perspective of a company doing business in Kansas, when the high court gives you a ruling, you need to comply with the ruling. You [cannot] take a position that flies in the face of a [Kansas] Supreme Court ruling. When the [Kansas] Supreme Court made its decision, [that is] the point at which the company's decision-making stops. ${ }^{219}$

For GateHouse, that meant that it had to order its employee, O’Brien, to comply with the court order to turn over her notes and testify. According to Hurst, he reminded O'Brien at that point that, if she wished to defy the court's order and continue to protect her confidential source's identity, then she would need to arrange for independent counsel. ${ }^{220}$ Hurst recalled having the conversation previously with O'Brien as well. ${ }^{221}$ As he recalled:

That was one of the first conversations that occurred when we first got involved. We said right now, the company is defending your interest. The only time there could be a possible conflict of interest is if the court says we [do not] have legal grounds and you decide you [do not] want to testify. [After the Kansas Supreme Court ruled,] we had that conversation [again] and we said the company made its decision, the

216. Id.

217. Carlson, supra note 13 ("The relationship between the Dodge City Daily Globe and one of its reporters fractured Wednesday, the day she was found in contempt of court for not appearing to answer a prosecutor's questions about a confidential source.”).

218. Hurst Interview, supra note 104.

219. Id.

220. Id.

221. Id. 
company is not able to advocate for anything more, we need to get you independent counsel involved. ${ }^{222}$

O’Brien tells a dramatically different story. She contends that Hurst attempted to back her into a corner, insisting that she had to testifydivulging both the name of her source and her unpublished notes-if she were to continue to be provided with counsel. ${ }^{223}$ O'Brien stated: "At the end, Bill Hurst told me straight out that the only way I could have legal representation from GateHouse was to do whatever I had to do to avoid contempt" and "basically in the end [I] have to tell [Malone] anything he wants to know, or [they are] not going to pay for it."224

Asked if he believes O'Brien misunderstood his explanation about diverging interests and O'Brien's need to seek independent counsel, Hurst declined to speculate. ${ }^{225}$

I think she was confused by a lot of things. I think she had a lot of things going on. Suffice it to say, I [do not] think she fully understood the gravity of going to get your own lawyer and looking at these issues because she [did not] do it until very, very late in the day. ${ }^{226}$

Seeming to bolster O'Brien's story that GateHouse was, at best, unclear with her, Dodge City Daily Globe publisher Darrel Adams contradicted what Hurst claims to have told O’Brien. ${ }^{227}$ Adams believed O'Brien never was told that GateHouse would not continue to support her in court. ${ }^{228}$ According to Adams, "Most papers would stand behind the reporter and do [what is] right. If the situation happened again, we would stand behind our reporter."229 When asked if he believed GateHouse and the Globe stood behind O'Brien for the duration of the suit, including the time following the Kansas Supreme Court's ruling, Adams replied unequivocally: "Yes, we did."230

Adams's statement is in line with an excerpt of an internal GateHouse memo, sent from corporate executives to publishers, that was

222. Id.

223. O’Brien Interview, supra note 1.

224. Id.

225. Hurst Interview, supra note 104.

226. Id.

227. Adams Interview, supra note 175.

228. Id.

229. Id.

230. Id. 
“leaked” to a media commentator. ${ }^{231}$ The memo, which said O’Brien's firing was not related to the subpoena battle, read in part: "But we can assure you, without violating any privacy or confidentiality concerns, that GateHouse Media vigorously stood behind Ms. O’Brien during the recent, highly publicized court case, all at our cost and expense.”232

\section{O’Brien Makes a “Stupid” Decision}

Following the Kansas Supreme Court's decision to stay out of the case, Malone scheduled an inquisition hearing for O’Brien to testify on Wednesday, February 10, 2010. With events rapidly unfolding and feeling like she could not trust the GateHouse attorney, O'Brien said she reached out to the Reporters Committee for Freedom of the Press (RCFP). ${ }^{233}$ The RCFP is a not-for-profit group formed in 1970 in response to increasing numbers of government subpoenas seeking the names of journalists' confidential sources. ${ }^{234}$ The group's primary role remains providing free legal help to journalists. ${ }^{235}$ As O'Brien recalled, the organization's executive director, Lucy Dalglish, declined to help. ${ }^{236}$ According to O’Brien, Dalglish had been told by Hurst that GateHouse was capable of representing both the Globe and O'Brien. ${ }^{237}$ O’Brien said she told Dalglish that was not true, but Dalglish believed Hurst. ${ }^{238}$

O’Brien felt trapped. ${ }^{239}$ So, she made what she later called a dumb mistake: she decided to skip the scheduled court hearing. ${ }^{240}$ She now concedes her mistake: "I know now how stupid that was and how bad it made me look. ... . [But] I [was not] going to go to court with an attorney who [did not] share my interests."241

231. Billy Dennis, More B.S. from GateHouse Media About Fired Reporter, PEORIA PUNDIT, (Mar. 11, 2010 3:12 PM), http://pundit.blogpeoria.com/2010/03/11/more-b-s-from-gatehouse-mediaabout-fired-reporter.

232. Id.

233. O’Brien Interview, supra note 1.

234. History, RePS. COMMITTEE FOR FREEDOM OF THE PRESS, http://www.rcfp.org/aboutus/history (last visited Apr. 7, 2012).

235. Id.

236. Carlson, supra note 13.

237. O’Brien Interview, supra note 1; Carlson, supra note 13.

238. O’Brien Interview, supra note 1; Carlson, supra note 13.

239. O’Brien Interview, supra note 1.

240. Id.; Carlson, supra note 13.

241. O’Brien Interview, supra note 1. 


\section{O’Brien Speaks Out}

After O'Brien failed to appear in court, the judge found her in contempt and fined her $\$ 1,000$ per day until she appeared in court and testified. ${ }^{242}$ O'Brien also began speaking out, telling media outlets that her newspaper had ordered her to reveal her confidential source and had "disrupted her attempts to seek outside help from a national journalism group." 243 The national journalism group O’Brien referred to was the RCFP. ${ }^{244}$ O'Brien was particularly angered by comments made by its executive director, Lucy Dalglish. ${ }^{245}$ O’Brien claimed that she explained to the RCFP that she had unsuccessfully sought help from all thirteen criminal defense attorneys in Dodge City, and none wanted to take her case. $^{246}$ She asked for the RCFP's help, but O'Brien claimed that Dalglish turned her down. ${ }^{247}$ Then, Dalglish told the Topeka CapitalJournal that she had never seen circumstances like these in her decade at the RCFP. ${ }^{248}$ Dalglish continued: “[O’Brien is] very distraught, very suspicious. From what I can tell, her employer was willing to pay for legal counsel to accompany her (on Wednesday), and for whatever reason it appears she has chosen not to do that."249

Dalglish offered strong criticism of O'Brien's failure to appear in court, noting: "What she did was really stick a thumb in the judge's eye today. Even if [you are] not going to answer questions, you still have to go to court." 250 An editor at the Globe told the Capital-Journal that newspaper officials “were taken aback [when O’Brien did not] show up."251

O'Brien said she felt as though the head of a national journalism advocacy group essentially had called her a liar-something that was enough to leave a reporter "with her name ruined and her career destroyed.”252 Indeed, media commentator Dan Kennedy questioned O'Brien's conduct after reading about the story on the Topeka Capital-

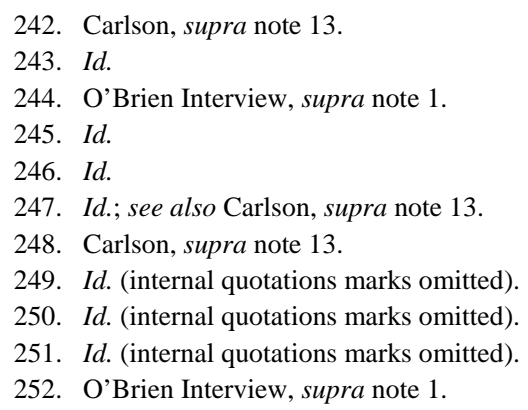


Journal's website, writing: “[I $\mathrm{am}]$ going to have to side with management on this one. The reason: ... If Lucy Dalglish [does not] stand up for you on a freedom-of-the-press issue, then [you are] wrong." 253 In an update to his original post later the same day, Kennedy noted, without further clarification, that "Dalglish takes a rather different stance on the RCFP Web site, saying she finds O'Brien's termination 'unusual' and 'quite disturbing.,"254

\section{A Confidential Source Reveals His Identity; O’Brien Testifies}

In the end, neither the lawyers and the judges nor the media advocates solved O'Brien's dilemma. Instead, it was the source himself, who trusted O'Brien and agreed to reveal his identity to the authorities to prevent O’Brien from going to jail. ${ }^{255}$

The court rescheduled the inquisition for the following Friday. By that time, O'Brien's source had released her from her pledge of confidentiality. $^{256}$ And also by that point, the RCFP and the Kansas Press Association ultimately had helped to line up an independent attorney-Mark Johnson, a partner at the Kansas City, Mo., office of Sonnenschein Nath \& Rosenthal LLP, ${ }^{257}$ now known as SNR Denton-to represent O'Brien at the hearing. ${ }^{258}$ Johnson is a longtime media attorney, teaches a media law class at the University of Kansas William Allen White School of Journalism and Mass Communications, and had been preparing to write a brief as amicus curiae for the Kansas Supreme Court before the court declined to accept the case. ${ }^{259}$ Johnson made the six-hour drive from Kansas City to Dodge City, met with O’Brien, met with the prosecutor to develop an "understanding" about the scope of the hearing, represented O’Brien during the hour-long afternoon hearing, and

253. Dan Kennedy, At Gatehouse, as Elsewhere, the Rich Get Richer, MEdia NATION (Mar. 9, 2010, 10:45 AM), http://www.dankennedy.net/2010/03/09/at-gatehouse-as-elsewhere-the-rich-getricher.

254. Id.

255. O’Brien Interview, supra note 1.

256. Id.; see Cristina Abello, Kansas Reporter Testifies After Confidential Source Comes Forward, REPS. COMMITTEE FOR FREEDOM OF THE PRESS (Feb. 16, 2010), http://www.rcfp.com/ node/97847.

257. Abello, supra note 256.

258. Telephone Interview with Mark Johnson, Partner, Sonnenschein Nath \& Rosenthal LLP (now SNR Denton) (March 11, 2010) [hereinafter Johnson Interview] (notes on file with author).

259. Id. 
then made the six-hour drive back to Kansas City—all in a single day. ${ }^{260}$ During the closed inquisition, Johnson recalled that the only thing O'Brien testified to that was not contained in her original published report was the name of her confidential source, who by that time had already spoken with the prosecutor. ${ }^{261}$ As Johnson explained:

In the absence of a shield law, there [was not] a whole lot she could do and that I could do to prevent her from testifying in the first place.... Judge Love was quite relieved to see her on Friday. I [do not] think he was at all interested in putting her in jail or imposing any kind of fine on her. He very quickly rescinded his order finding her in contempt. ${ }^{262}$

\section{Hard Feelings Persist}

O'Brien remained angry. The situation prompted a terse exchange in the comments section of an article about the case that was posted on the RCFP's website. ${ }^{263}$ A commenter who identified herself as Claire O'Brien and made many of the same statements that O'Brien made to the author of this Article, vented her frustrations about the way the RCFP had treated her. ${ }^{264}$ The post took Dalglish to task for the comments she made to the Topeka Capital-Journal:

Reporters who fight for months to protect the safety of their sources tend to become "distraught and suspicious" when told by their corporate attorneys that future legal support depends on giving those sources up.

That stress level tends to mount when said reporter risks corporate wrath and appeals to the RCFP for legal protection-only to be met with a skepticism and disbelief that leaves her more exposed than ever to retaliation.

[It is] one thing to doubt a reporter's word when she tells you [she is] being pressured to disclose- or pay the bills herself. [It is] another thing entirely for the director of the RCFP, one of the standard bearers

\footnotetext{
260. Id.

261. Id.

262. Id.

263. See Cristina Abello, Kansas Reporter Misses Court Date to Testify, Held in Contempt, REPS. COMMITTEE FOR FREEDOM OF THE PRESS (Feb. 10, 2010), www.rcfp.org/node/97840. The article had originally been available with comments on the RCFP's website; however, the comments are no longer available.

264. Id.
} 
of journalism, to announce that skepticism to the press. ${ }^{265}$ 
Dalglish responded to O’Brien's post with this message:

Protecting sources can be difficult and stressful, particularly in states without shield laws. The Reporters Committee became involved in this case almost three weeks ago. We are very pleased that we were able to fulfill our mandate to help find an attorney that Ms. [O]'Brien found acceptable, for whom she did not have to personally pay for. We hope her experience helps lead to a statutory reporters privilege in Kansas. ${ }^{266}$

Dalglish's comments led to a long response from O'Brien, in which she outlined many of her frustrations with GateHouse and with the RCFP. It read, in part:

You [did not] spend anything close to three weeks helping me, Lucy. It was more like one week-you caused your own delays by refusing to believe me. Inexplicably, you took the company lawyers' word instead, withdrew your initial offer of help at the last minute, and ordered me to find my own lawyer if I [did not] like ... my current counsel. You refused to believe that that counsel had directed me in no uncertain terms to disclose "whatever it takes to avoid a contempt charge[."] That last is a direct quote from the lawyer directing the case, made on Friday, Feb. 5.

Your characterization of your assistance as "enthusiastic" astonishes me. Most of the time, you lectured me severely, reacting with frustration and skepticism to almost every [piece] of information I gave you. If you had simply believed me, my gratitude and cooperation would have amazed you — but I was sick and tired of being pushed around by lawyers, corporate executives, and the Kansas Press Association. I was weary of defending my truthfulness, my professionalism, and my good name. No one was going to protect my source but me, so I stood alone and did the best I could. I sat at home and waited for the police to arrive and take me into custody-while I waited, you called: not to find out what happened or ask how I was, but to snap "Well, you really screwed up!"267

Nearly everyone consulted for this Article described O'Brien's emotional state at the time of the inquisition as fragile at best. For example, Gene Lehmann, the managing editor of the Globe, conceded that he "was very concerned about [O’Brien's] health toward the last two 
weeks of this playing out.",268 Lehmann continued: "[O’Brien] seemed to be really in a fog about the whole thing. I was worried about [her]."269

Even Terry Malone, the prosecutor who had subpoenaed O’Brien, voiced his concerns over O’Brien's well-being: ${ }^{270}$

I was concerned a bit about [O’Brien's], I guess, emotional state of being. [She is] not a young person, and I think she had invested a lot of emotions into the case. And I think she was very set on what she wanted to do and was going to do as a reporter. That worried me that she would indeed say, "Hey, Judge, throw me in jail." Nobody wanted that. That was my concern, I know it was Judge Love's concern, I know it was her employer's concern. This had been a very stressful situation for her and hopefully we could let some air out of it because nobody, and I mean nobody, wanted to fine her or hold her in contempt for any reason. ${ }^{271}$

Indeed, after initially cooperating with the author of this Article, O’Brien later asked the author to share notes from interviews with others involved with the case, including Globe officials and the attorney for GateHouse. When the author of this Article declined to do so, O'Brien threatened to have the author deposed during what O'Brien promised would be a defamation lawsuit against certain individuals connected to this case.

In an interview, Dalglish declined to talk about the specifics of what happened between the RCFP and O'Brien, but she did explain that:

[O'Brien is] not satisfied with the services we provided. We are confident, particularly on the Friday that she did go to court, [that] we were instrumental in ensuring that she was represented by outstanding counsel that she did not have to pay for. Nevertheless, [she is] angry. At some point you just have to move on. [I am] sorry she feels that way, but we just need to move on. ${ }^{272}$

For her part, O’Brien says of course she was distraught. ${ }^{273}$ She had been subpoenaed to testify, she planned to protect her source, and she

\footnotetext{
268. Lehmann Interview, supra note 182.

269. Id.

270. Malone Interview, supra note 93.

271. Id.

272. Telephone Interview with Lucy Dalglish, Exec. Dir., Reporters Comm. for Freedom of the Press (April 15, 2010) [hereinafter Dalglish Interview] (notes on file with author).

273. O’Brien Interview, supra note 1.
} 
believed she was headed to jail. ${ }^{274}$ On top of that, she believed her employer lied to her and was trying to sabotage her career. ${ }^{275}$ And her name was being dragged through the mud in the media. ${ }^{276}$

Meanwhile, O’Brien said her confidential source was "freaking out.”277 He called O’Brien frequently to check in with her and determine whether she intended to continue to protect him. ${ }^{278}$ As O’Brien recalled: "He called me two days before [the rescheduled inquisition] and said, '[What is] your limit?' I said, '[It is] you! If you want me to tell them, I will. If not, I have an obligation not to disclose.' I think more than anything else, that shows the bond between a reporter and a source."279

A few weeks after O’Brien's inquisition, Sam Bonilla entered a guilty plea to voluntary manslaughter and aggravated battery. ${ }^{280}$ The voluntary manslaughter plea reflected "an unreasonable but honest belief that deadly force was justified.”281 On April 6, 2010, Bonilla was sentenced to more than six years in prison for killing Holt and wounding Brunson. ${ }^{282}$

\section{O’Brien’s Termination}

In the days after O’Brien skipped the court hearing, she noticed that things had changed at work-literally, in some cases. ${ }^{283}$ O'Brien said in an interview that the locks were changed at the Globe, leaving her as the sole newsroom employee without a key. ${ }^{284}$ O’Brien said she was strictly limited to working precisely an eight-hour shift, even though she had more work to do than she could complete in that time. ${ }^{285}$ She claimed that she was forced, against her wishes, to sign paperwork indicating that

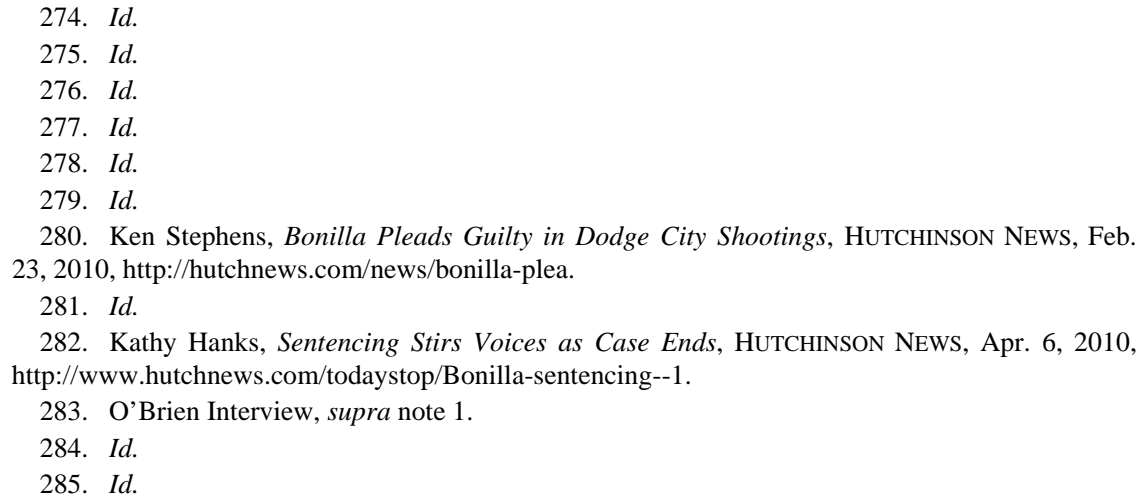


she had defamed the company. ${ }^{286}$ And she said her supervisors filed formal paperwork for even trivial workplace violations, such as turning a story in a few minutes past deadline. ${ }^{287}$ O’Brien was terminated on March 5, 2010. ${ }^{288}$

"I feel like [I have] been set up to fail," she observed in an interview about a week before she was fired. ${ }^{289}$ "They want to fire me, but [there is] too much publicity. But I feel like my career at GateHouse is over. That is a First Amendment issue, too, if that can happen to a reporter. The reporter ends up with her name ruined and her career destroyed.”290

For their part, GateHouse officials declined to comment about O’Brien's termination, calling it a "personnel matter"291 or a "personnel issue." 292 While declining to go into specifics, GateHouse attorney Hurst maintained that "[h]er employment status had nothing to do with this case. That dealt with matters [for which] she was long on notice."293 The aforementioned leaked memo from corporate executives to publishers echoes Hurst's contention. The memo claimed that "[r]ecent developments [with O’Brien's termination] are absolutely not related to any part of that legal battle.”294

O’Brien believes that she made herself a target by insisting to fight the subpoena in the first place, challenging her attorneys along the way, asking to be included in discussions about legal strategy, and speaking out after she believed the company had turned its back on her. ${ }^{295}$ She firmly believes that she was fired in retaliation for speaking out against her newspaper and its corporate owner, GateHouse. ${ }^{296}$ "The whole intent of the First Amendment is also destroyed if a journalist [who defies a subpoena] goes back to work and finds the locks changed. That is going

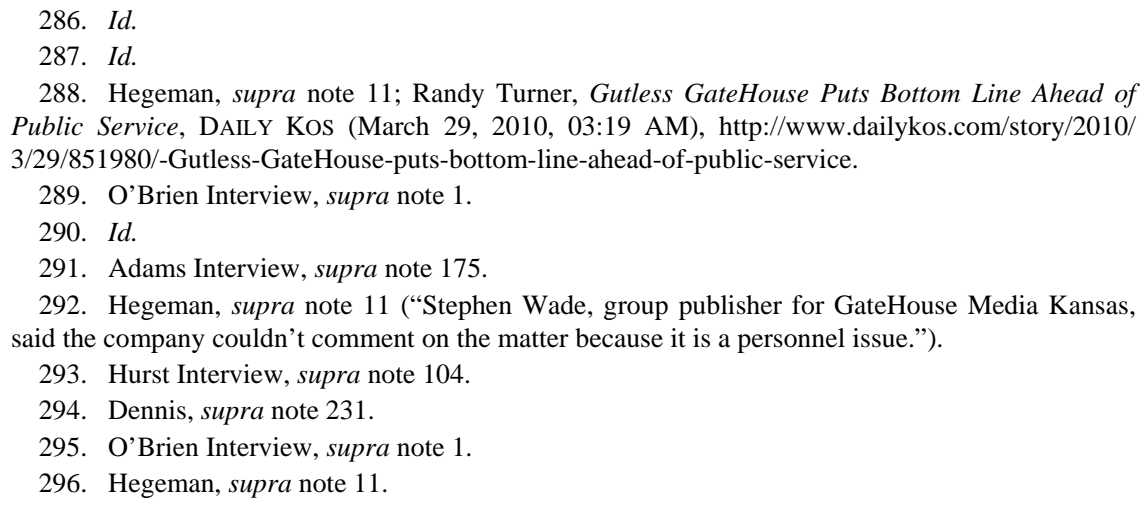


to kill a free press.”297

\section{Putting the Case into Context—with a Capital "C"}

Mark Johnson, the media attorney who represented O'Brien during the inquisition hearing, said Judge Love's initial decision about whether O'Brien had to testify was flawed because he ultimately seemed to settle on a standard of mere relevance. ${ }^{298}$ According to Johnson, the standard is inappropriate because "[a]nything is arguably relevant.... [That is] the absolute lowest bar you can imagine.... The challenge is, if [that is] simply the test, then there is no test."299

But after traveling to Dodge City, he said he had a greater appreciation for the big picture that the judge faced. ${ }^{300}$ Dodge City is in a time of flux. ${ }^{301}$ The Latino immigrant population is swelling, while the town is "dominated by a very conservative white elite and is represented in Topeka by very conservative Republican legislators who [do not] really have to worry about the immigrant population because they [do not] vote.”302 Then, this case emerged, involving a Latino man accused of murdering a white man with alleged ties to a white supremacist organization. ${ }^{303}$ As Johnson explained:

Like I tell my [journalism] students, ... there is little "c" and big "C" context. Little " $\mathrm{c}$ " is where the guy [Bonilla] was standing [at the time of the shooting]. But [it is] just as important—and sometimes more important - to look at what is going on in the community at the time and why the judge might have felt pressured to come out a certain way. I think in this case, he wanted to make absolutely sure that all of the relevant evidence-all of the relevant evidence-was laid out before the jury so the jury could make as informed a decision as possible. Plus, I [do not] think judges like the idea of certain people saying, sorry, [I am] special, I [do not] have to testify. ${ }^{304}$

Malone also said O’Brien’s initial story unnecessarily stirred racial

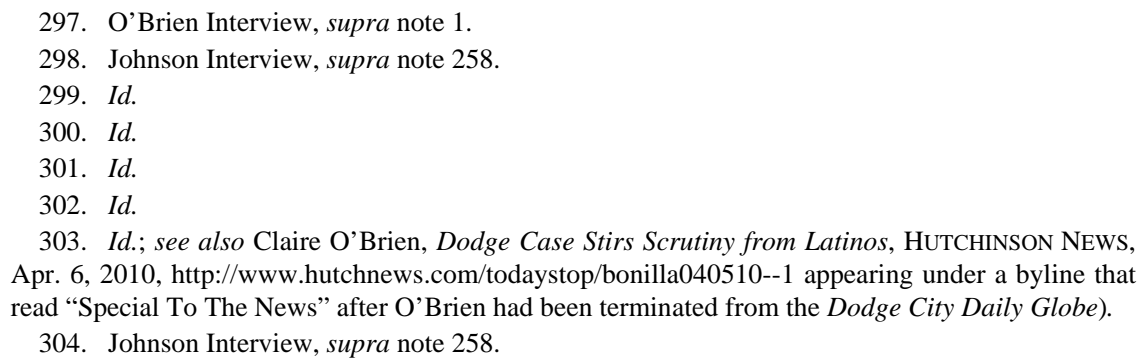


tensions in Dodge City. ${ }^{305}$ Malone traced the whole saga back to O'Brien's trusted source, the bail bondsman Rebecca Escalante. ${ }^{306}$ Escalante was friends with Sam Bonilla and occasionally worked with him. ${ }^{307}$ Escalante arranged for the jailhouse interview of Bonilla. ${ }^{308}$ Escalante found the confidential source to back up her and Bonilla's concerns about Bonilla being in danger. ${ }^{309}$ And Escalante vouched for the confidential source's veracity. ${ }^{310}$ When investigators followed up on the leads in O'Brien's story, they turned up little in the way of a credible threat. $^{311}$ Escalante herself dodged police investigators' questions out of court, claimed to have a faulty memory while under oath, and ultimately exercised her Fifth Amendment right against self-incrimination when questioned during the inquisition. ${ }^{312}$ Malone painted an unflattering picture of O'Brien's involvement with Escalante and Bonilla:

[O]ur investigation of the matter led us to believe it was blown out of proportion ... to gain sympathy for Sam.... In my view, Claire got played. She got suckered into writing an article that I thought was fairly damaging to the tensions in our community between Hispanics and non-Hispanics. That was the most disturbing thing about the article. It was damaging to our community. ${ }^{313}$

Judge Daniel Love also publicly lamented that the story had harmed the community. ${ }^{314}$ In scathing remarks before he sentenced Bonilla, Love said that the killing - and specifically O'Brien's coverage of the case- - had fanned racial tensions. ${ }^{315}$ Love singled out O’Brien by name, taking her to task for talking only to Bonilla and leaving out comments from others-beginning with her first report. ${ }^{316}$ "From that point on," the judge told a packed courtroom, "the focal point of nearly every article about this case mentioned or focused on Sam Bonilla's self-

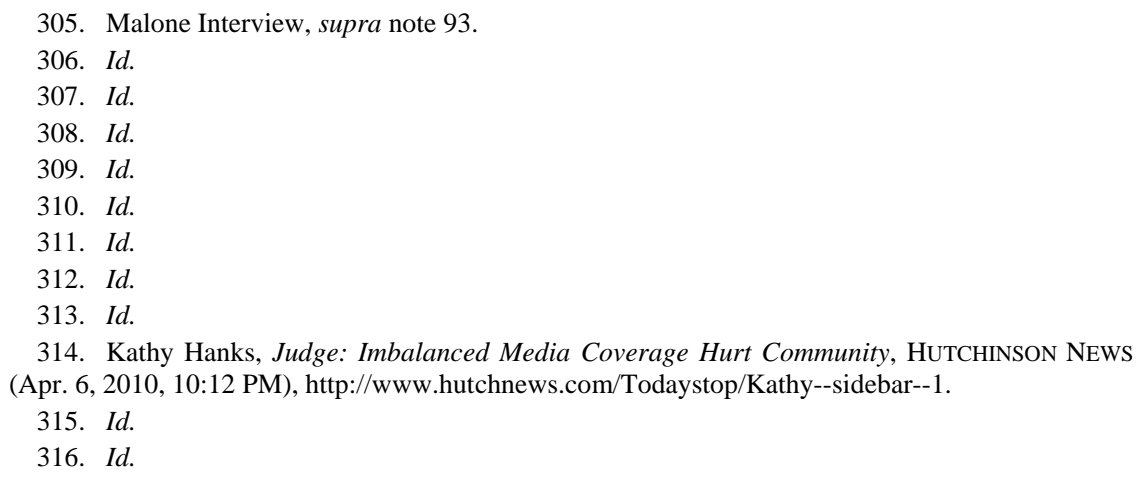


defense theory.”317 The judge went on to say:

Many people in Dodge City, wanting to believe what they read, have concluded that Sam Bonilla's actions were undoubtedly in self-defense. This comes through O’Brien's articles that have said little about the other witnesses' testimony and has totally omitted preliminary hearing testimony of the two Hispanic women who were in the river bottom, witnessed what occurred, and gave testimony that made the selfdefense claim unlikely to be believed by any jury. ${ }^{318}$

\section{The Kansas Legislature's Response}

\section{The Politics Behind the New Shield Law}

Perhaps sensitive to the concern that the media desired "special" treatment, the Kansas Press Association (KPA) and other advocates of a media shield law set out to craft a qualified media shield law. Under such an approach, reporters would have some protection from "fishing expeditions," during which lazy litigators or prosecutors expect reporters to do their legwork for them. ${ }^{319}$ But, under the proper circumstancesand after an evidentiary hearing-the court could compel reporters to testify if certain conditions were met. ${ }^{320}$

The KPA, along with several other news media advocates, had been pushing for a media shield law in Kansas for years. ${ }^{321}$ The shield law was a perennial loser, seeming to flame out in the bowels of a legislative committee every year. ${ }^{322}$ In fact, a media shield law bill had been introduced in the Senate in 2007, and after it went nowhere, the bill re-

317. Id.

318. Id.

319. Dion Lefler, Senate Judiciary Committee Oks 'Shield Law', Wichita EAgLE, Mar. 19, 2010, http://www.kansas.com/2010/03/19/1232035_senate-judiciary-committee-oks.html ("Kent Cornish, executive director of the [Kansas Association of Broadcasters], said the bill should cut down on 'fishing expeditions' by lawyers who demand that TV stations turn over all the footage they shoot at news scenes.").

320. KAn. StAT. AnN. § 60-482 (Supp. 2011).

321. Doug Anstaett, We Made Sausage, and Out Popped a Shield Law, KAN. Publisher (Kan. Press Ass'n, Topeka Kan.), Apr. 7, 2010, at 9 available at http://www.kspress.com/sites/default/ files/kspub0407.pdf (noting that passage of a shield law "took years to accomplish ... [a]nd... required a tag-team effort from our members, legislators and others when the stars finally lined up in just the right formation").

322. KPA's March to a Shield Law—Step by Step, KAN. PuBLISHER (Kan. Press Ass'n, Topeka, Kan.), Apr. 7, 2010, at 10, available at http://www.kspress.com/sites/default/files/kspub0407.pdf [hereinafter KPA's March to a Shield Law]. 
emerged in 2008. ${ }^{323}$ Co-sponsored by then-Senate Majority Leader Derek Schmidt, a Republican from Independence, and Senate Minority Leader Anthony Hensley, a Democrat from Topeka, the bill had powerful allies and appeared cued up for success.

Schmidt, who earned his undergraduate degree in journalism from the University of Kansas, where he spent one semester as the editor of the student newspaper, said he was eager to be a sponsor of the legislation. ${ }^{324}$ As Schmidt explained:

I suppose [it is] my journalism background, but I think there is some limit on the power of government to compel a journalist to testify about information gathered. If there [are not] limitations on that, then journalists are nothing more than ordinary citizens with pencils. Now, [that is] not inherently bad, but the Constitution has suggested that journalists are something more- [it is] the newsgathering, watchdog, light-shining function. ${ }^{325}$

But the bill languished in the Senate Judiciary Committee, which tabled it in 2008, effectively killing it for the session. ${ }^{326}$ It was reintroduced in $2009,{ }^{327}$ but the committee again tabled it following a hearing that year. ${ }^{328}$ These were not the only times a shield law had failed to advance in Kansas. For example, Kansas lawmakers considered a shield law bill in 2002. ${ }^{329}$ And a summer study committee considered it again in 2003, but the panel unanimously rejected it. ${ }^{330}$

But in 2010, with the O’Brien case making headlines and capturing attention across the state and the nation, media advocates believed that "the stars finally lined up in just the right formation." 331 In a wrap-up column included in a monthly newsletter to KPA members, KPA Executive Director Doug Anstaett celebrated the passage of the shield

323. S.B. 313, 2008 Leg., Reg. Sess. (Kan. 2008); Eric David, Wins and Losses in Effort to Expand Shield Protections, NEwSROOM L. BLOG (Jan. 6, 2009), http://www.newsroomlawblog.com /2009/01/articles/shield-laws/wins-and-losses-in-effort-to-expand-shield-protections/.

324. Telephone Interview with Derek Schmidt, Majority Leader, Kan. Senate (Apr. 16, 2010) [hereinafter Schmidt Interview] (notes on file with author).

325. Id.

326. Telephone Interview with Terry Bruce, Senator, Kan. Senate (Apr. 13, 2010) [hereinafter Bruce Interview] (notes on file with author).

327. S.B. 211, 2009 Leg., Reg. Sess. (Kan. 2009).

328. KPA's March to a Shield Law, supra note 322.

329. Walker, supra note 19, at $1217 \mathrm{nn} .19-20$.

330. Id.

331. Anstaett, supra note 321. 
law-and directly linked its passage to O’Brien's plight. ${ }^{332}$ Anstaett recalled that in previous legislative sessions "the single greatest stumbling block to passage was the lack of anecdotal evidence that illustrated the need." 333 The subpoena and subsequent court battle involving O'Brien offered "the perfect storm" to demonstrate to lawmakers that there was a deficiency in the law. ${ }^{334}$ In fact, Anstaett observed, "The [Kansas Supreme C] ourt's curt, out-of-hand dismissal of the case apparently even alarmed those outside the journalism profession. We now had our anecdotal evidence.”335

Indeed, Lucy Dalglish, the executive director of the RCFP, believes that real-life examples highlighting the need for a shield law are crucial to successfully enacting such protections. ${ }^{336}$ As Dalglish explained:

In every state where [we have] gotten a law passed, and on the Hill [in Washington, D.C.], it is always more useful to have a recent example. This can be very complicated statutory drafting, and people can have a hard time understanding how these laws work. But if you can use an illustration for them, [then] they usually understand the situation a little bit better. $^{33}$

Buoyed by O’Brien's real-life example, media advocates realized that they had to capitalize on the momentum. ${ }^{338}$ Media advocates believed their chances to get a bill through the Kansas Legislature in 2010 would be greatest by beginning in the Senate, where Schmidt and Hensley's bill had been introduced the previous two sessions. ${ }^{339}$ Anstaett and Richard Gannon, a lobbyist for the KPA, perceived Senator Terry Bruce, a Republican from Hutchinson, as the key to unlocking the bill from the Senate Judiciary Committee. ${ }^{340}$ Bruce had voted against the measure in committee the year before, ${ }^{341}$ but he understood that his vote

332. Id.

333. Id.

334. Id.

335. Id.

336. Dalglish Interview, supra note 272.

337. Id.

338. Interview with Richard Gannon, Gov'tal Affairs Dir., Kan. Press Ass'n (Feb. 18, 2010) [hereinafter Gannon Interview].

339. Id.

340. Anstaett, supra note 321 ("But the key element, Rich Gannon and I believe, was when Hutchinson Sen. Terry Bruce stepped into the picture.”); Bruce Interview, supra note 326; Gannon Interview, supra note 338.

341. Bruce Interview, supra note 326; Gannon Interview, supra note 338. 
would carry sway among others on the committee. ${ }^{342}$ Prodded in part by the editor of his hometown newspaper, ${ }^{343}$ Bruce agreed to meet with media advocates. ${ }^{344}$ They quickly discovered they "really [were not] that far apart." 345 As Bruce explained: "Last year, I had questions, concerns [because] I [did not] know how it was going to work and [did not] see any real need for it. Then the Dodge City case came up. That brought the shield law into the limelight again.”346

Before becoming a state senator, Bruce had worked as a prosecutor in Reno County and as communications director for then-House Majority Leader Representative Clay Aurand, a Republican from Courtland. ${ }^{347}$ Those two experiences helped provide a foundation to understand both the needs of prosecutors and the needs of the media-though he was quick to joke that he never imagined he would "be the champion of the Kansas press.” ${ }^{348}$ In talking with media representatives, Bruce said he realized the biggest issue in Kansas was that case law precedents and statutes simply were not very clear, leaving litigants to forge their own procedural trail before getting to the merits of a dispute. ${ }^{349}$ Bruce explained this plight as "people spin[ning] their wheels-both sidestrying to find out what the protocol is to quash a subpoena. ${ }^{350}$ In his mind this "burn[ed] up a lot of legal fees.",351

Malone, the Ford County prosecutor who issued the subpoena to O’Brien, informed his local lawmakers he did not oppose the shield law. ${ }^{352}$ To the contrary, he would welcome some clarification of the procedure for such situations. ${ }^{353}$ He went so far as to "embrace the shield

\footnotetext{
342. Bruce Interview, supra note 326.

343. Shield Law Passes Legislature, KAN. Publisher (Kan. Press Ass'n, Topeka, Kan.), Apr. 7, 2010, at 1 available at http://www.kspress.com/sites/default/files/kspub0407.pdf (“John D. Montgomery, Hutchinson News editor and publisher, also played a pivotal role in the process because three Hutchinson legislators were in the middle of the issue: Sen. Terry Bruce, House Speaker Mike O’Neal and Rep. Jan Pauls ....”)

344. Anstaett, supra note 321.

345. Id.

346. Bruce Interview, supra note 326.

347. Terry Bruce, BALLOTPEDIA, http://www.ballotpedia.org/wiki/index.php/Terry_Bruce (last visited Apr. 16, 2012).

348. Bruce Interview, supra note 326.

349. Id.

350. Id.

351. Id.

352. Malone Interview, supra note 93.

353. Id.
} 
law" because "[i]t would make things a lot easier." ${ }^{354}$ He believes that it would have made all the difference in O’Brien's case. ${ }^{355}$

Bruce and media advocates began with the bill introduced in 2009. ${ }^{356}$ They modified it, borrowing language from Branzburg as well as media

354. Id.

355. Id.

356. Bruce Interview, supra note 326. 
shield laws in other states, including Washington and Colorado, to forge a compromise. ${ }^{357}$ Bruce offered a succinct summary:

What it really offers is, one, a process by which this can be litigated and, two, it establishes the test, which is basically the common law test articulated in Branzburg with the addition of the [cannot] be "obtained by alternative means" [language in section 60-482(a)(2)]. We tied a few things down, and it does give journalists a little bit of protection. And, in the end, it does offer some clarity to the process. Nobody was asking for the moon. We just got enough people to agree with us. ${ }^{358}$

Anstaett, the executive director of the KPA, agreed that there was much compromise involved to reach agreement. ${ }^{359}$ "There was armtwisting, back-scratching, horse-trading and give-and-take along the way.... We offered what are called 'balloon amendments' back and forth, massaging the wording, occasionally giving something to get something else." 360

Because a key deadline had passed by the time momentum developed behind the shield law bill, lawmakers could not attempt to pass the Schmidt-Hensley sponsored Senate Bill 211.361 Instead, senators used a legislative procedural maneuver known as a "gut and go," a process by which the contents of a bill that has already passed one chamber are deleted and replaced with new provisions. ${ }^{362}$ The procedure is essentially a shortcut, allowing lawmakers to skip ahead to the conference committee stage after a bill has passed only one chamber, rather than waiting for the second chamber to take up the measure in the traditional fashion. ${ }^{363}$ Senate Judiciary Committee Senator Tim Owens, a Republican from Overland Park, offered a bill that pertained to marriage licenses to be the "vehicle" for the shield law provisions. ${ }^{364}$ Originally, the bill would have waived marriage license fees for those

\footnotetext{
357. Id.; see also Anstaett, supra note 321.

358. Bruce Interview, supra note 326.

359. Anstaett, supra note 321.

360. Id.

361. KPA's March to a Shield Law, supra note 322.

362. Jason Probst, Legislative Tactics, Hutchinson NEws, Mar. 2, 2010, http://www.hutchnews.com/Editorialblogs/Gut-and-Go-edit ("[W]hen a bill [does not] stand much of chance of making it out of committee, legislators can fall back on the 'gut and go' procedure, which allows lawmakers to move forward a bill by stripping out the contents of another bill and inserting new language for an entirely different piece of legislation.”).

363. Id. ("Little doubt [that] this method proves useful when a bill faces opposition from a stubborn committee chairperson who [will not] even open the bill for discussion.”).

364. KPA's March to a Shield Law, supra note 322.
} 
living in poverty. ${ }^{365}$ Though the marriage license fees bill had passed the House, Owens did not think there would be time for the Senate to consider the measure in $2010 .^{366}$ So, out went the marriage license contents, and in went the shield law provisions. ${ }^{367}$

Once media advocates and lawmakers had reached agreement, the years-old logjam on the issue was broken. The Senate Judiciary Committee advanced the measure to the full Senate with ease. ${ }^{368}$ It passed the Senate on March 23, 2010, by a vote of 39-1. ${ }^{369}$

The measure then moved to a conference committee, where it initially met resistance from the House conferees, including Representative Lance Kinzer, a Republican from Olathe and the chairman of the House Judiciary Committee. ${ }^{370}$ Then-Senator Schmidt, who was closely involved in negotiations over the bill, said the whole compromise nearly collapsed late one evening when talks broke down with the House conferees. ${ }^{371}$ Schmidt believes that 2010 marked a change in strategy for media shield law advocates. ${ }^{372}$ Rather than advocate for special protection for journalists, they couched their argument as "an honest and good faith attempt to clarify and codify the already existing case law in Kansas." 373 But suddenly, Kinzer cast the strategy into doubt when he questioned whether one of the key aspects of the proposed balancing test in the bill-a requirement that the party seeking disclosure should first attempt to obtain the information from alternative sources-had ever been recognized by a Kansas court. ${ }^{374}$ Schmidt made a frantic call to Mike Kautsch, a media law professor at the University of Kansas School of Law and a former dean of the University of Kansas School of Journalism. ${ }^{375}$ Kautsch, who had been closely involved in drafting the 2010 compromise, quickly found key

365. Carpenter, supra note 12.

366. KPA's March to a Shield Law, supra note 322.

367. Id. ("We were searching for a House passed bill that would ultimately allow us to procedurally 'speed up' the process.").

368. Id.

369. Nadia Tamez-Robledo, Kansas Passes Reporter's Shield Law, News Media \& L., Spring 2010, at 7, 7.

370. Bruce Interview, supra note 326; Schmidt Interview, supra note 324.

371. Schmidt Interview, supra note 324.

372. Id.

373. Id.

374. Id.

375. Id. 
case law on point in Berst v. Chipman. ${ }^{376}$ Kinzer was persuaded. ${ }^{377}$

The full House voted to approve the shield law measure by a vote of $116-3$, and the Senate once again gave its approval to the conference committee's minor changes by a 39-1 vote. ${ }^{378}$ Governor Mark Parkinson signed the bill into law on April 15, 2010. ${ }^{379}$ In a statement, the governor observed:

Our founding fathers were very meticulous in making certain that our country, including members of the press, received the necessary protections for freedom. The shield law demonstrates that Kansas upholds that belief and respects a reporter's discretion in disclosing information and sources. While we understand the need for information under extraordinary circumstances, we must allow journalists to perform their jobs without fear of prosecution and continue bringing the news home to Kansans. ${ }^{380}$

For her part, even before the shield law was passed into law, O’Brien said she felt used by media advocates who initially championed her cause, then distanced themselves from her once she skipped her court date. ${ }^{381}$ Of course, in the end, the KPA and the RCFP did help arrange for O’Brien to have independent counsel at no cost to her. ${ }^{382}$ But the media advocates openly acknowledge that highlighting the need for a media shield law to protect all reporters was just as important to them as defending O'Brien from the specific subpoena she faced. Complicated as it was, O’Brien's saga was a real-life example of why media advocates believe that a shield law is an important and necessary public policy. Without such a compelling case illustrating the need for a shield law, the law would not have passed. ${ }^{383}$

376. Id.; Berst v. Chipman, 653 P.2d 107, 115 (Kan. 1982) (“The failure to exhaust available alternative sources of information was the determinative factor in the refusal to compel discovery of confidential material in several cases." (gathering cases)).

377. Schmidt Interview, supra note 324.

378. Cristina Abello, Kansas Shield Bill Awaits Governor's Signature, REPS. COMMITTEE FOR FREEDOM OF THE PRESS (Mar. 31, 2010), http://www.rcfp.org/node/97915.

379. Morgan, supra note 207.

380. Id.

381. O’Brien Interview, supra note 1.

382. See supra Part II.C.

383. Robert Arcamona, Kansas Shield Law Awaits Governor's Signature: Ripe Fruit From a Bewildering Tree, Citizen MEdiA L. PROJECT (Apr. 1, 2010), http://www.citmedialaw.org/blog/ 2010/kansas-shield-law-awaits-governor's-signature-ripe-fruit-from-bewildering-tree. "As one commentator put it, the O’Brien saga was, well, 'weird.' But, from the ashes of this story came something that had been years in the making - a shield law for Kansas's reporters, and a good one at that. While few want to see the O’Brien case unfold a second time, the media attention surrounding 


\section{The Policy Contained Within the New Shield Law}

One of the more revolutionary parts of the Kansas shield law, as compared to those in other states, is that the Kansas law defines "journalist" to include not only a "publisher, editor, reporter[,] or other person employed by a newspaper, magazine, news wire service, television station[,] or radio station who gathers, receives[,] or processes information for communication to the public," but also an "online journal in the regular business of newsgathering and disseminating news or information to the public." 384 The change means that it "seems to cover bloggers and other non-traditional journalists so long as they engage in 'regular' journalism., 385

The centerpiece of the new Kansas shield law, however, is the protection it affords to those who fall under its definition of journalist. Under the law, no journalist can be compelled to turn over notes or unpublished information, and no court may hold a journalist in contempt for refusing to do so, unless certain narrow circumstances exist. ${ }^{386}$ The key to reaching compromise on the law's passage was the inclusion of the balancing test, which allows prosecutors and litigants to overcome the shield law's protection. ${ }^{387}$ The only way to overcome the shield is for the party seeking the information to prove "by a preponderance of the evidence" that the information being sought: "(1) [i]s material and relevant to the proceeding for which the disclosure is sought; (2) could not, after a showing of reasonable effort, be obtained by readily available alternative means; and (3) is of a compelling interest.",388

The statute defines "compelling interest" as "evidence likely to be admissible and [that] has probative value that is likely to outweigh any harm done to the free dissemination of information to the public through the activities of journalists." 389 Such evidence "includes, but is not limited to: (1) [t]he prevention of a certain miscarriage of justice; or (2)

\footnotetext{
it did highlight the need for a shield law.” Id. (citing Kennedy, supra note 253).

384. KAn. StAT. ANN. § 60-480(a) (Supp. 2011); see also Arcamona, supra note 383 ("While a Kansas court will have to authoritatively define the term 'online journal,' the [law] seems to cover bloggers and other non-traditional journalists so long as they engage in 'regular' journalism. This question, whether bloggers should be protected by shield laws, has provoked vigorous debate surrounding the proposed federal shield law.”).

385. Arcamona, supra note 383.

386. KAN. STAT. ANN. §§ 60-481 to -482 .

387. Id. § 60-482(a).

388. Id. § 60-482(a)(1)-(3).

389. Id. § 60-482(b).
} 
an imminent act that would result in death or great bodily harm.”390 The statute goes on to specify that "[i]nterests that are not compelling include, but are not limited to, those of parties whose litigation lacks sufficient grounds, is abusive[,] or is brought in bad faith.”391

The statute outlines the procedure that litigants and courts must follow when determining whether the qualified privilege protects a journalist from a subpoena. According to the statute, as well as interviews with those who wrote it, the process would proceed as follows: After the issuance of a subpoena, a journalist would file a motion to quash it. ${ }^{392}$ Alternatively, in a civil case, the party receiving a subpoena of nonparty business records may file objections, including the protections afforded by the Kansas shield law. ${ }^{393}$ A subpoenaed journalist would then produce the records only following the issuance of an order by the court on motion of the party seeking the records. ${ }^{394}$ After a motion to quash or an order to compel (in a civil case), the court would conduct an open hearing during which neither side would disclose the confidential information. ${ }^{395}$ Rather, the court would assess the arguments of both sides, with the party seeking disclosure bearing the burden of proof. ${ }^{396}$ The party seeking disclosure must meet the threeelement test set out in section 60-482(a) by a "preponderance of the evidence." 397 After the hearing, the court, in its discretion, could order the journalist to turn over the evidence for "an in camera inspection to determine if such disclosure is admissible.”" ${ }^{\text {"98 }}$ According to Bruce:

[T]he court could immediately say yes or no, [it is] clear cut[; o]r the court could say, "I need to look at the evidence myself in chambers.”... The court could make a determination that [an in camera inspection is] not necessary, but I suspect the court will hold a

\footnotetext{
390. Id. § 60-482(b)(1)-(2).

391. Id. § 60-482(b).

392. Id. § 60-483; see Bruce Interview, supra note 326; Schmidt Interview, supra note 324.

393. KAN. STAT. ANN. § 60-245a(b).

394. Id.

395. KAN. StAT. ANN. § 60-483; Bruce Interview, supra note 326; Schmidt Interview, supra note 324 .

396. KAN. STAT. ANN. §§ 60-482 to -483; Bruce Interview, supra note 326; Schmidt Interview, supra note 324.

397. KAn. StAT. AnN. § 60-482(a); Bruce Interview, supra note 326; Schmidt Interview, supra note 324.

398. Id. § 60-483; Bruce Interview, supra note 326; Schmidt Interview, supra note 324.
} 
hearing and then apply the arguments to the evidence at hand. ${ }^{399}$

At the conclusion of the initial hearing-or following the in camera inspection, if the court chooses to avail itself of that option-the court can order the disclosure of the evidence only if the court "specifically finds" that the evidence sought "is admissible and that its probative value outweighs any harm to the free dissemination of information to the public through the activities of journalists." 400 The court may make such a determination only after weighing whether the evidence sought is relevant, of a "compelling interest" and could not be obtained by alternative means. ${ }^{401}$ Schmidt understood that, "[a]t the end of the day, this is always going to be a balancing process. . . . And that has to be, ultimately, a case-by-case, fact-specific process. [We have] just provided the courts with a little more guidance about how the balance has to be struck.",402

The statute also specifies that if either the party seeking disclosure or the party invoking the privilege did not have a "reasonable basis" for their respective position, then the court can order them to pay the other side's attorney's fees. ${ }^{403}$ Finally, the statute itself mandates that it should "not be construed to create or imply any limitation on or to otherwise affect a privilege guaranteed by the constitutions of the United States or the state of Kansas."

\section{E. Putting the New Media Shield Law to the Test}

\section{Tragedy in Wichita}

It did not take long for a Kansas court to take the new statutory reporter's privilege for a test drive. The first-and, so far, onlyapplication of the state's new shield law arose in a civil action filed in the wake of a five-year-old boy's death at an indoor playground in Wichita. ${ }^{405}$ Matthew Branham died March 22, 2010, after he was

\footnotetext{
399. Bruce Interview, supra note 326.

400. KAn. StAT. ANN. §60-483; Bruce Interview, supra note 326; Schmidt Interview, supra note 324.

401. KAn. STAT. ANN. § 60-482 (a)(1)-(3); Bruce Interview, supra note 326; Schmidt Interview, supra note 324.

402. Schmidt Interview, supra note 324.

403. KAN. STAT. ANN. § 60-484.

404. Id. § 60-485.

405. Suzanne Perez Tobias, Two Workers Say They Were Taught to 'Launch' Kids on Inflatable
} 
launched from an inflatable ride and fell. ${ }^{406}$ According to a wrongful death action filed by the victim's family, the boy landed head-first on a concrete floor at the business, Pure Entertainment, which was owned and operated by the defendant, Moonwalks for Fun, Inc. ${ }^{407}$

The boy's tragic death made headlines in Wichita. The Wichita Eagle soon ran a story suggesting that the boy's family had been using one of the inflatable rides in the same manner that they had seen demonstrated by employees at Pure Entertainment. ${ }^{408}$ Further, the story cited two employees - anonymously - who said the Pure Entertainment manager "taught them and other employees how to operate the ride last year." 409 One employee told the Eagle that the manager told employees to operate the ride in a manner it was not intended to be used, in such a way that the employees would "launch the kids, and [they would] go flying in the air." 410 The employees, who provided their age but not their name "because of concerns for their safety and future employment," told the reporter that they "honestly did not feel comfortable doing it, but [that is] the way he [the manager] showed us."

\section{The Analysis in Ruggiero v. Moonwalks for Fun, Inc.}

Not surprisingly, the victim's family wanted to use the information provided by the former employees in a lawsuit against the owner and operator of Pure Entertainment. But first, the family's attorney, Todd Shadid, needed their names. Shadid issued a business records subpoena to the Eagle. ${ }^{412}$ The Eagle, represented by Wichita media lawyer Lyndon W. Vix, filed objections. ${ }^{413}$ The subpoena, served on the Editor and Vice President of the Eagle, sought records that "pertain to reporting by Suzanne Perez Tobias on the death of Matthew Branham, and

\footnotetext{
Ride, WiChitA EAGLE, May 2, 2010, at A1.

406. Id.

407. Plaintiff's Memorandum Supporting Enforcement of Business Records Subpoena Issued to Wichita Eagle and Beacon Publishing Co., Inc. at 2. Ruggero v. Moonwalks for Fun, Inc., No. 10CV-3383 (Kan. Dist. Ct. Oct. 26, 2010) [hereinafter Business Records Memorandum].

408. Tobias, supra note 405.

409. Id.

410. Id.

411. Id.

412. Subpoena of Business Records, Ruggero v. Moonwalks for Fun, Inc., No. 10-CV-3383 (Kan. Dist. Ct. Sep. 14, 2010) [hereinafter Business Records Subpoena].

413. Objections of Wichita Eagle and Beacon Publishing Company, Inc., to Subpoena of Business Records, Ruggero v. Moonwalks for Fun, Inc., No. 10-CV-3383 (Kan. Dist. Ct. Sep. 22, 2010) [hereinafter Objections Memorandum].
} 
Moonwalks for Fun, Inc. and Pure Entertainment."414 Specifically, the subpoena sought the name, address, and phone number of the employees Tobias interviewed and quoted anonymously, all notes and statements in connection with the interview of the two employees, all notes and statements in connection with other interviews of named employees of Pure Entertainment, all photographs of the ride in question, and contact information for other customers interviewed by Tobias and quoted in her story. $^{415}$

\section{a. The Wichita Eagle’s Objections}

In briefs and oral arguments following the subpoena, the arguments and analysis played out almost precisely as those interviewed for this Article had predicted they would —albeit after a slight procedural hiccup. The Eagle filed objections to the subpoena, claiming the information sought was privileged, pursuant to both the new media shield law and existing First Amendment common law precedent in Kansas. ${ }^{416}$ In an interview months later, Vix said that rather than reply to his objections with a Motion to Compel, Shadid simply set the dispute for a hearing before Sedgwick County District Court Judge William Wooley. ${ }^{417}$ Vix wanted to brief the matter before going in front of the judge to argue, so he filed what he titled a "Memorandum in Support of Objections of Wichita Eagle and Beacon Publishing Company, Inc., to Subpoena of Business Records." ${ }^{18}$ In a footnote, Vix wrote that "plaintiff has not filed a motion and therefore the Eagle can only speculate as to the arguments she might raise in response to the objections. This is particularly curious given the fact that plaintiff bears the burden of establishing grounds sufficient to overcome the asserted privileges."419

Notwithstanding the procedural irregularities, the underlying content of each side's argument appeared to unfold as the shield law's authors anticipated. The Eagle based its objection to the business records

414. Business Records Subpoena, supra note 412, at 1.

415. Id. at $1-2$.

416. See Objections Memorandum, supra note 413, at 1-2.

417. Telephone Interview with Lyndon W. Vix, Member, Fleeson, Gooing, Coulson \& Kitch, L.L.C. (Jan. 19, 2012) [hereinafter Vix Interview] (notes on file with author).

418. Memorandum in Support of Objections of Wichita Eagle and Beacon Publishing Company, Inc., to Subpoena of Business Records, Ruggero v. Moonwalks for Fun, Inc., No. 10-CV-3383 (Kan. Dist. Ct. Oct. 26, 2010).

419. Id. at $11 \mathrm{n} .7$. 
subpoena first on the test outlined in the new shield law, which the memorandum quoted at length. ${ }^{420}$ The Eagle's brief underscored language in the shield law, which notes that "[t]he rights and privileges protected by [the shield law] are in addition to any other rights guaranteed by the constitutions of the United States and the State of Kansas." 421 The brief then outlined Branzburg, In re Pennington, and Silkwood. ${ }^{422}$ Finally, the brief went on to argue that "an extensive constitutional analysis" was unnecessary because "[a]ll of the information sought is plainly protected by the shield law." "423

Although the Eagle argued that it was "not compelled to do so by the shield law or otherwise," the Eagle undertook to outline in general terms what information it had that was responsive to the subpoena. ${ }^{424}$ The heart of the dispute concerned the names of the employees who were quoted anonymously. ${ }^{425}$ The Eagle conceded that while the individuals' identities "might be material and relevant in the present proceedings, it is far less clear that such information is 'of a compelling interest' as required" by the shield law. ${ }^{426}$ The Eagle argued that "a 'compelling interest' is present when the information in question is of such importance that the inability to obtain it will result in a 'certain miscarriage of justice.”, "427 But here, the newspaper article itself said the two individuals quoted "were not present when the accident at issue in this case occurred. The information they could provide, therefore, could not help establish any element of the plaintiff's case." ${ }^{228}$

Finally, the Eagle argued that the Plaintiff simply had not done enough to try to learn the information she sought through the subpoena. ${ }^{429}$ Specifically, the Eagle argued that the newspaper article contained the ages of the two employees. ${ }^{430}$ The Eagle's brief went on to criticize the Plaintiff's strategy:

420. Id. at 4-5 (quoting 2010 Kan. Sess. Laws 928 (codified as Kan. StAT. AnN. § 60-482 (Supp. 2011))).

421. Id. at 5 (quoting 2010 Kan. Sess. Laws 928 (codified as KAN. STAT. ANN. § 60-485)).

422. Id. at 6-9.

423. Id. at 9 .

424. Id. at 11-15.

425. See id. at 12

426. Id.

427. Id.

428. Id.

429. Id. at 13 .

430. Id. 
With even the most minimal of discovery efforts[,] plaintiff could obtain a list of defendants' past and present employees. . . .

It does not appear that plaintiff has done anything to try to learn the identities of the former employees before issuing a subpoena to the Eagle. This is precisely the sort of lazy litigation practice that gave rise to shield laws in the first place. Plaintiff's lack of effort, in and of itself, compels that the Eagle's objection be sustained. ${ }^{431}$

\section{b. The Plaintiff's Response}

The Plaintiff responded with a brief that framed the issue as follows:

A journalist must disclose information that is material and relevant to pending litigation, not readily available by other means, and is of a compelling interest. Plaintiff's lawsuit asserts that defendants improperly set up and misused an inflatable ride causing the death of a child. The Wichita Eagle reported that two former employees said defendant taught them to misuse the inflatable ride. Should the Wichita Eagle disclose the identity of the two former employees? ? $^{432}$

The brief then contended that Plaintiff had met its burden. The Plaintiff argued the information sought was "material and relevant[,] . . . not obtainable by readily available alternative means[, and]... of compelling interest." 433 The Plaintiff's six-page brief, in mostly conclusory statements, argued that the information was "not obtainable by readily available alternative means" because the Plaintiff would "have to contact every former employee and hope that each one responds truthfully. Such effort is not reasonable and does not guarantee identification or discovery of the information sought" from the newspaper. ${ }^{434}$ The brief argued that the information that the anonymously quoted employees could provide was of a compelling interest because it had "enormous probative value" and the lawsuit concerned "a public safety issue." ${ }^{35}$ The brief did not address any information sought by the subpoena other than the identities of the anonymously quoted employees.

431. Id.

432. Business Records Memorandum, supra note 407, at 1-2.

433. Id. at 4.

434. Id. at 5.

435. Id. 


\section{c. Oral Arguments and the Judge’s Ruling}

During oral arguments, Vix, a member at the Wichita law firm of Fleeson, Gooing, Coulson \& Kitch, L.L.C. and the Eagle's longtime attorney, relied on the idea that the acquisition of a reporter's unpublished notes through a subpoena cannot provide a shortcut for litigants. ${ }^{436}$ He recalled quoting from his brief, which quoted a Texas case that held:

The law is clear that compulsory disclosure of a reporter's confidential sources should be the last resort for obtaining information; all other means must first be exhausted. Respondent must fulfill his obligation to exhaust alternative sources even though he fears that the investigation may be time consuming, costly, and unproductive. ${ }^{437}$

Vix argued that the very discovery that the Plaintiff was trying to avoid was the exact discovery required to overcome the protection of the shield law. ${ }^{438}$ In the end, Judge Wooley ruled in favor of the Eagle, sustaining their objections to the subpoena in a curt, handwritten Order scrawled on a minute sheet, stating simply: "objections of Eagle are sustained without prejudice.”439

Vix said he is not sure whether the judge ever reached an in-depth balancing exercise, perhaps finding simply that the Plaintiff's subpoena was “premature." 440 As Vix explained:

My sense is what we basically were able to do was to get him to say, you guys need to go out and make an effort, plaintiff, before you can yank the media into this as your source for information. ... [The media shield law] certainly gave us something concrete that we could put in front of the court. We had a pretty good common law test in Silkwood that the Tenth Circuit had adopted, but it [was not] as clear in the state courts. Courts are reluctant if I say, [here is] something from the Tenth Circuit, they kind of turn up their nose at that. It [does not] have the same effect as if you say, look, [here is] a statute that says what [you

436. See Vix Interview, supra note 417.

437. Objections Memorandum, supra note 413, at 13 (quoting Lenhart v. Thomas, 944 F. Supp. 525, 530 (S.D. Tex. 1996))

438. Vix Interview, supra note 417.

439. Civil Department Motion Minutes Sheet, Ruggiero v. Moonwalks for Fun Inc., No. 10-CV3383 (Kan. Dist. Ct. Oct. 26, 2010); see also Ron Sylvester, Eagle Reporter Prevails Under New Shield Law, What the Judge Ate FOR BREAKFAst (Oct. 26, 2010, 4:44 PM), http://blogs.kansas.com/courts/tag/william-woolley/.

440. Vix Interview, supra note 417. 
are] supposed to do. ${ }^{441}$

Despite the protection afforded to the media under the new shield law, Vix believes the law's biggest test would come in a criminal case, rather than a civil case where the stakes are not as high:

[It is] not like truth, justice, and the American way depended on how this case turned out. When [you have] got a criminal defendant with various constitutional protections, [we are] going to be a little more hard-pressed.... The shield law is far from airtight. [It is] not an absolute privilege .... There may be instances where a judge who really wants [privileged information] can hang his hat on something in the statute and say, I did the balancing test and the media has to produce. $^{442}$

\section{THE APPROPRIATE FRAMEWORK FOR O’BRIEN AND HER CASE}

\section{A. The Ford County District Court Judge Improperly Relied on a Standard of Mere Relevancy}

Returning to Dodge City and the O'Brien case, back before the state had enacted a shield law, Judge Love was asked to analyze whether O’Brien could be compelled to divulge her source's name under Kansas common law. If Judge Love's order following arguments on whether to quash Malone's subpoenas were a law school exam, he would not have passed. Judge Love completely failed to step through the analysis and spell out each of his conclusions. Rather, he merely made conclusory statements that were utterly unsupported. ${ }^{443}$ In deciding not to quash the prosecutor's subpoena, Love purported to apply both a balancing test and a relevancy approach-and to arrive at the same conclusion either way. ${ }^{444}$ In fact, because he provided no analysis to support it, Love skipped the balancing test altogether. Instead, he relied solely on a relevance standard. Not only was mere relevancy the incorrect standard to apply, but had he correctly applied the balancing test, the outcome would have been different. Because Judge Love did not apply the proper

441. Id.

442. Id.

443. In re Inquisition to Inquire Into Certain Alleged Violations of the Laws of Kan., No. 09 MR 163, at 5 (Kan. Dist. Ct. Dec. 9, 2009) ("In this case, when applying the balancing test, it is clear to the Court that the need for this information outweighs the news reporter's privilege of confidentiality.").

444. Id. at 4-6. 
analytical approach, his resulting opinion is of little value. 
1. The United States Supreme Court and the Kansas Supreme Court Have Endorsed a Balancing Test

\section{a. Branzburg v. Hayes}

The starting point in a pre-shield-law analysis of a reporter's privilege is the seminal United States Supreme Court decision Branzburg $v$. Hayes. ${ }^{445}$ Although the prosecutor in the Dodge City case argued that Branzburg offers no privilege whatsoever, this is untrue for three reasons. First, the controlling opinion answered only the narrow question of "whether requiring newsmen to appear and testify before state or federal grand juries abridges the freedom of speech and press guaranteed by the First Amendment." 446 Thus, the court considered simply whether the First Amendment could protect journalists from even appearing at such a hearing. The court concluded that the First Amendment, of course, does not. ${ }^{447}$ The question of whether there may be some constitutional limits on the type or scope of questions that litigants can compel a journalist to answer, however, is more complicated.

Second, the Branzburg decision must be read in tandem with Justice Powell's pivotal concurrence. One cannot find a "majority" opinion in Branzburg without Justice Powell; four justices alone do not add up to a Supreme Court majority. Therefore, one must view Justice Powell's position as limiting the majority's holding — just as he expressly indicated in his concurring opinion. ${ }^{448}$ And the heart of Justice Powell's short concurrence is hard to miss: "we do not hold... that state and federal authorities are free to 'annex' the news media as 'an investigative arm of government.",449 Justice Powell invites members of the media to file a motion to quash any subpoena that amounts to "harassment" of journalists or "bear[s] only a remote and tenuous relationship to the subject of the investigation, or if he has some other reason to believe that his testimony implicates confidential source relationships without a

\footnotetext{
445. 408 U.S. 665 (1972).

446. Id. at 667 .

447. Id.

448. Id. at 709 (Powell, J., concurring) ("I add this brief statement to emphasize what seems to me to be the limited nature of the Court's holding." (emphasis added)).

449. Id. (quoting id. at 725 (Stewart, J., dissenting)).
} 
legitimate need of law enforcement."450 He then concludes by articulating his view of the standard:

The asserted claim to privilege should be judged on its facts by the striking of a proper balance between freedom of the press and the obligation of all citizens to give relevant testimony with respect to criminal conduct. The balance of these vital constitutional and societal interests on a case-by-case basis accords with the tried and traditional way of adjudicating such questions. ${ }^{451}$

Justice Powell used the word "balance" or "balancing" six times in a concurring opinion that is only 501 words long. ${ }^{452}$

Furthermore, in later Supreme Court decisions, Justice Powell again wrote separately to reemphasize the importance of his concurring opinion in Branzburg. Six years after Branzburg, in Zurcher v. Stanford Daily, Justice Powell wrote a concurring opinion in which he noted that his concurrence in Branzburg, simply stated, stood for the notion that "in considering a motion to quash a subpoena directed to a newsman, the court should balance the competing values of a free press and the societal interest in detecting and prosecuting crime." ${ }^{453}$ And again, in a dissenting opinion Justice Powell authored in Saxbe v. Washington Post Co., he wrote that he "emphasized the limited nature of the Branzburg holding in my concurring opinion." 454 Justice Powell further explained that "[t]aken in its entirety... Branzburg does not endorse [a] sweeping ... rejection of First Amendment challenges to restraints on access to news." 455 Justice Powell concluded that "a fair reading of the majority's analysis in Branzburg makes plain that the result hinged on an assessment of the competing societal interests involved in that case rather than on any determination that First Amendment freedoms were not implicated." 456

Finally, aside from the question of how to properly interpret whether a concurring opinion can temper the holding of four other justices, it is important to note that Justice White himself, in his opinion, conceded that courts must offer at least some protection to journalists during the

\footnotetext{
450. Id. at 709-10.

451. Id. at 710 .

452. See id. at 709-10.

453. 436 U.S. 547, 570 n.3 (1978) (Powell, J., concurring).

454. 417 U.S. 843, 859 (1974) (Powell, J., dissenting).

455. Id.

456. Id. at 859-60 (citing Branzburg, 408 U.S. at 700-01).
} 
news-gathering stage of the reporting process. Justice White wrote that the Court "do[es] not question the significance of free speech, press, or assembly to the country's welfare. Nor is it suggested that news gathering does not quality for First Amendment protection; without some protection for seeking out the news, freedom of the press could be eviscerated." "457 Justice White seemed to weigh competing interests as he worked through his analysis. It is important to remember that the underlying facts in Branzburg involved reporters who had witnessed their confidential sources actually breaking the law. ${ }^{458}$ He seemed to bristle at the journalists' argument that reporters could decline to testify before a grand jury about criminal conduct that they personally had observed. Justice White wrote that "[t]he preference for anonymity of those confidential informants involved in actual criminal conduct is presumably a product of their desire to escape criminal prosecution, and this preference, while understandable, is hardly deserving of constitutional protection." 459 Justice White goes on to write that "we cannot seriously entertain the notion that the First Amendment protects a newsman's agreement to conceal the criminal conduct of his source, or evidence thereof, on the theory that it is better to write about crime than to do something about it."460

Justice White even appeared to endorse at least some balancing. He quoted and applied one precedent holding that the government must "convincingly show a substantial relation between the information sought and a subject of overriding and compelling state interest."461 Thus, it is unclear whether Justice White himself would have ruled that a reporter must reveal a source like O’Brien's-one who is not a criminal defendant or even suspected of a crime.

\section{b. In re Pennington}

Let there be no doubt that in Kansas, under In re Pennington, a journalist "has a limited privilege of confidentiality of information and identity of news sources." ${ }^{462}$ The Kansas Supreme Court recognized this

\footnotetext{
457. Branzburg, 408 U.S. at 681.

458. Id. at 667-70.

459. Id. at 691 .

460. Id. at 692 .

461. Id. at 700-01 (quoting Gibson v. Fla. Legislative Investigation Comm., 372 U.S. 539, 546 (1963)) (internal quotation marks omitted).

462. State v. Sandstrom (In re Pennington), 581 P.2d 812, 814 (Kan. 1978).
} 
limited privilege following a close reading and application of Branzburg. ${ }^{463}$ It is true, as both Ford County Attorney Terry Malone argued and Judge Love noted, that "a news reporter's privilege is more tenuous in a criminal proceeding than in a civil case." 464 But the court tempers this by noting that simply because a subpoena is issued in a criminal case does not mean the privilege vanishes entirely. ${ }^{465}$ As the court noted, "[i]f that were true, no privilege would exist for a news reporter summoned in a criminal case."

The court goes on to hold that the proper test is relevance, coupled with "a test of balancing the need of the defendant for the information or the identity of the news source against the privilege of the news reporter." ${ }^{\text {"67 }}$ The fact that the court recognizes this essential balancing of interests lies the heart of the test constructed in In re Pennington. Without the balancing test, the test for whether a subpoena should be quashed would be relevancy alone-as Judge Love appeared to hold. But mere relevance alone cannot be the standard under Kansas common law precedent. If it were, just as the Kansas Supreme Court warned, no privilege would exist at all ${ }^{468}$ because the definition of "relevant evidence" is so broad. ${ }^{469}$ Under the Federal Rules of Evidence, practically anything could be considered admissible.

\section{Using Silkwood to Apply Branzburg and In re Pennington to the O’Brien Subpoena}

It is thus unquestionable that, even before passage of the Kansas shield law, news reporters in Kansas enjoyed a constitutional privilege to refuse to testify under certain circumstances. It is for the courts to weigh the circumstances on a case-by-case basis to determine whether the privilege should shield the reporter. Prior to the passage of the Kansas shield law, the best place for a Kansas court to find precisely what a balancing test should look like was Silkwood v. Kerr-McGee Corp. ${ }^{470}$

\footnotetext{
463. Id. at 814-15.

464. Id. at 815 .

465. Id.

466. Id.

467. Id.

468. Id.

469. FED. R. EVID. 401 ("Evidence is relevant if: (a) it has any tendency to make a fact more or less probable than it would be without the evidence; and (b) the fact is of consequence in determining the action.”).

470. 563 F.2d 433 (10th Cir. 1977); see generally Walker, supra note 19 (advocating for the
} 
The Tenth Circuit in Silkwood provided a distillation of Branzburg and the many other courts that have considered the balancing test. The Silkwood court listed four factors for courts to work through: (1) "[w]hether the party seeking information has independently attempted to obtain the information elsewhere and has been unsuccessful”; (2) "[w]hether the information goes to the heart of the matter"; (3) "[w]hether the information is of certain relevance"; (4) "[t]he type of controversy.",471

\section{a. An Independent Attempt to Obtain the Information Sought}

If one were to apply the test described in Silkwood to the facts surrounding O'Brien's subpoena, the outcome would have been different. In fact, the prosecutor in Dodge City would stumble on the first factor in Silkwood because he failed to conduct any independent investigation at all prior to subpoenaing O'Brien's notes and testimony. In affidavits attached to the State's response to GateHouse's motion to quash the subpoena, Malone indicated that he elicited testimony from a bail bondsman on November 17, 2009 $9^{472}$ - three weeks after he issued subpoenas to O'Brien on October 27, 2009. ${ }^{473}$ In a similar affidavit attached to his brief to the Kansas Supreme Court, Malone added additional detail, noting that he dispatched a police detective to talk to Escalante, the bail bondsman, at some unspecified time after his initial conversation with O'Brien. ${ }^{474}$ When Escalante was reluctant to talk, Malone subpoenaed her. ${ }^{475}$ These few conversations with a bail bondsman appear to be the only independent investigation of the information contained in O'Brien's newspaper story about Sam Bonilla. Escalante did provide at least a few names. ${ }^{476}$ Those names should have served as leads. Police could have talked to the friends and neighbors of the individual named in O'Brien's story as potentially being a danger to Bonilla. Instead, Malone took a shortcut, subpoenaing O'Brien before attempting to obtain the information through the alternative means of

\footnotetext{
codification of Silkwood).

471. 563 F.2d at 438 (citing Garland v. Torre, 259 F.2d 545 (2d Cir. 1958)).

472. State's Response to Motion to Quash Subpoena, supra note 145, at 19.

473. Petition for Writ of Mandamus, supra note 9, at Ex. B.

474. State's Response to Emergency Stay Request, supra note 200, at Ex. 1.

475. Id.

476. Id.
} 
good, old-fashioned police work. This factor tips strongly in O’Brien's favor.

\section{b. Whether the Information Goes to the Heart of the Matter}

Malone's subpoenas sought two distinct types of information. First, he was interested in any statements made by Bonilla to O’Brien. Second, he sought information O'Brien collected from a confidential source who purported to know that certain individuals in the community wished to harm Bonilla. Arguably, the first category does go "to the heart of the matter," given that Bonilla was the defendant in a murder case. Moreover, as a criminal defendant, Bonilla could choose not to testify at his own trial, thereby keeping the statements he made to O'Brien out of court. When police interviewed Bonilla, however, he had told them the same self-defense story he told O'Brien. The point of his interview with O'Brien was to get his side of the story into the media, which previously had not included Bonilla's take on the shooting. From the investigators' perspective, he actually did not share anything new with O'Brien. Further, most of what he did share with O'Brien was contained in her news article. Investigators certainly had access to that information.

As for the second category of information-the alleged threats against Bonilla's safety - they appear to have nothing to do with the underlying criminal charges against Bonilla. According to O'Brien's published report, some members of the community were mad at Bonilla for what he was accused of doing. It would be hard to imagine that this went "to the heart of the matter" at hand, which was the prosecution of Bonilla for the shooting in the riverbed. The purported desire for retaliation after the shooting was completely unrelated to Malone's prosecution of Bonilla for the shooting. This is the very definition of a fishing expedition.

In hindsight, we know the information from the confidential source not only failed to go "to the heart of the matter," it in fact was not relevant at all. In an interview, Malone acknowledged that after the subpoenas, the testimony, the investigation, and ultimately, the discussions with the source once he revealed himself, there was very little information to be gleaned at all-and certainly nothing that went "to the heart of the matter." Malone recalled that the source did not offer much unique insight into the matter, claiming only that people were 
angry and that some had guns. ${ }^{477}$ While the court did not have access to that information, of course, it remains clear that tangential information from an anonymous source hardly goes "to the heart" of the underlying case. Thus, this factor also tips in O’Brien’s favor.

\section{c. Whether the Information Is of Certain Relevance}

As previously noted, nearly any evidence can be considered "relevant" to a given case. The definition is intentionally broad. The Silkwood court seemed to increase the threshold slightly by requiring the evidence sought to be of "certain relevance.",778 As previously noted, the information pertaining to whether Bonilla was in any danger arguably was not of certain relevance for the same reasons that it did not go "to the heart of the matter." Statements made by the defendant in a criminal murder case, however, certainly would be relevant. At least when it comes to those specific comments, this factor would tip toward Malone.

\section{d. The Type of Controversy}

The Bonilla case was a criminal case. As such, the reporter's privilege is "more tenuous" than in a civil case. ${ }^{479}$ Still, that is not to say that the privilege does not exist at all. If that were true, reporters would have no privilege at all in Kansas prior to the shield law's passage, and as previously discussed, that is simply not the case. Thus, this factor also tips in Malone's favor-but only slightly.

\section{The Outcome of the Balancing Test Under Silkwood}

Even Judge Love might have to agree-this was a close call. Decisions like this one that involve balancing competing interests are not easy, and judges must make fact-specific findings on a case-by-case basis. Here, two of the factors tipped strongly in O'Brien's favor: Malone did not attempt to find the information contained in O'Brien's notes from alternative sources, and the information he sought did not go to the heart of the matter. Further, only a portion of the evidence sought

477. Malone Interview, supra note 93.

478. Silkwood v. Kerr-McGee Corp., 563 F.2d 433, 438 (citing Garland v. Torre, 259 F.2d 545 (2d Cir. 1958)).

479. State v. Sandstrom (In re Pennington), 581 P.2d 812, 815 (Kan. 1978). 
was of "certain relevance"-and even that portion was information that investigators already had. Although it was a criminal case, that factor alone is not determinative. On balance, the judge should have found that Malone and police investigators needed to do more work of their own before Malone could compel O’Brien to turn over hers.

\section{B. The Argument to Quash Would Have Been Even Stronger Under the Kansas Shield Law}

Applying the facts of the O'Brien case to the newly enacted Kansas shield law, it is even more likely that the subpoena would have been quashed had the new law existed at the time. The Kansas shield law clearly would have applied because O'Brien would fall under the definition of "journalist" contained in the law, and she gained "information" while "acting as a journalist." 480 As such, the court would have held a hearing to consider the elements enumerated in the law.

\section{The Disclosure Sought Was Not "Material and Relevant" to the} Underlying Proceeding

As described above, "relevant" is a broad term under the federal rules of evidence. The drafters of the Kansas shield law, however, sought to rein in the definition a bit. First, the drafters required that the information sought be both relevant and material. ${ }^{481}$ This suggests a slightly higher threshold than mere relevance. Second, the drafters decided that the information sought must be material and relevant "to the proceeding for which the disclosure is sought." 482 Certainly the comments of a criminal defendant likely would be considered relevant, but, as discussed above, the police already had heard Bonilla's claims of self-defense. As for any information O'Brien had about angry people wishing to harm Bonilla after his arrest, such information could hardly be considered relevant "to the proceeding for which the disclosure is sought." Malone claimed that he was interested in investigating whether someone in the community wanted to harm Bonilla. ${ }^{483}$ Such information would pertain to a potential crime, not to the underlying proceeding for

\footnotetext{
480. KAn. StAT. ANN. § 60-480(a)-(c) (Supp. 2011).

481. Id. § 60-482(a)(1).

482. Id.

483. Malone Interview, supra note 93.
} 
which it was sought. This element tips almost entirely in O'Brien's favor.

2. The Information Sought Could Have Been Obtained by Alternative Means

The second element a court must consider under the new Kansas shield law is whether the information sought "could not, after a reasonable effort, be obtained by readily available alternative means." ${ }^{\text {"44 }}$ As discussed above, Malone did very little investigating - if any at allprior to subpoenaing Claire O'Brien. It would have been reasonable for him to interview those affiliated with the individual named in O’Brien's story as someone who wished to do harm to Bonilla. Police investigators could have talked to many individuals who had direct, first-hand knowledge of the situation-including Sam Bonilla and the surviving victim of the shooting. Instead, Malone immediately subpoenaed O'Brien. It was not that he failed to make a "reasonable effort" to obtain the information by alternative means; rather, he failed to make any effort to obtain the information by alternative means. This element tips strongly in O’Brien's favor.

\section{The Information Sought Was Not of a "Compelling Interest"}

At first blush, the prosecutor seems to have satisfied the third element. For the court to order disclosure, the information sought must be "of a compelling interest." 485 Without more, the comments of the defendant in a murder case and potential threats against his safety might seem "compelling" indeed. But the drafters of the shield law provided the court with significant guidance on this point. To be considered a "compelling interest," information sought must be "evidence likely to be admissible and ha[ve] probative value that is likely to outweigh any harm done to the free dissemination of information to the public through the activities of journalists." 486 The drafters then go on to provide two examples of information that would be considered to be of a compelling interest. First, evidence that would ensure " $[t]$ he prevention of a certain

484. KAn. STAT. ANN. § 60-482(a)(2).

485. Id. § 60-480(a)(3).

486. Id. § 60-482(b). 
miscarriage of justice. ${ }^{\text {„87 }}$ It is difficult to imagine that any statements made by either Bonilla, which the police already had, or O'Brien's confidential source, which did not pertain to the underlying murder case,

487. Id. § 60-482(b)(1). 
could prevent a miscarriage of justice. The information she had simply was not sufficiently relevant or important.

Second, the shield law's drafters provided that evidence might be sufficiently compelling if it could prevent "an imminent act that would result in death or great bodily harm." ${ }^{488}$ Bonilla's comments made in his own defense, outlining his self-defense theory, clearly do not fall into this category. The status of the comments from O'Brien's confidential source, however, is not as clear. In remarks attributed to her confidential source, O'Brien reported that white supremacists in Dodge City wished to do Bonilla harm and had access to a cache of weapons. Although these remarks initially might appear to reflect plans that could "result in death or great bodily harm," 489 on closer inspection, even these remarks do not fit under this umbrella. Even if the plans O'Brien wrote about were true, Bonilla only faced danger if he were released from jail. At the time of the subpoena, however, he was locked up safely in the custody of the Ford County Jail. It is not possible to argue that Bonilla faced an "imminent act" so long as he remained in jail.

Furthermore, the information the journalist could provide must outweigh "any harm done to the free dissemination of information to the public through the activities of journalists." ${ }^{\text {"90 }}$ The use of confidential sources can be controversial, but the fact remains that they are at times crucial to the mission of journalists. ${ }^{491}$ If sources believe that it is easy or routine for prosecutors or litigants to obtain the information they tell a reporter in confidence, then sources will be less likely to talk. This would diminish the information made available to the public and would harm society as a whole. Judges who apply the balancing test embodied in the Kansas shield law must not overlook the importance of a free press and its watchdog role.

Finally, the drafters of the Kansas shield law went on to specify that "[i]nterests that are not compelling include, but are not limited to, those of parties whose litigation lacks sufficient grounds, is abusive[,] or is brought in bad faith." ${ }^{492}$ Here, the "litigant" is a prosecutor who, without the reporter's testimony and without conducting his own investigation, has no grounds at all to charge further crimes. Such a nebulous probe is

488. Id. § 60-482(b)(2).

489. Id.

490. Id. § 60-482(b).

491. See generally Walker, supra note 19.

492. KAN. STAT. ANN. § 60-482(b). 
precisely the sort of compelled testimony from which the shield law was designed to protect journalists. All things considered, the third element tips strongly in O'Brien's favor as well.

Thus, under the Kansas shield law, the determination of whether to quash the subpoenas would be even more solidly in the newspaper's favor. The evidence sought is of only questionable relevance. The prosecutor had not done a sufficient independent investigation to attempt to gain the information through alternative means. And the information sought was not of a "compelling interest," as defined under the law. In short, without more work on the part of the prosecutor, O'Brien likely would have been permitted to exercise the reporter's privilege under the new Kansas shield law-had it existed at the time.

\section{CONCLUSION}

Of course, arguing how the new shield law would have affected O’Brien's case is a moot point. In fact, despite all the complicated twists and turns of O'Brien's saga, one thing seems certain: the Kansas Legislature never would have passed a media shield law without her reallife example highlighting the need for such a law.

In hindsight, the story that prompted the controversy probably should not have been published in the first place. It violated the newspaper's policies about the use of anonymous sources, and it did not receive proper internal vetting. Once it was published, the subpoena seeking the name of her confidential source and her notes from her jailhouse interview likely should have been quashed under the common law constitutional reporter's privilege that already existed in Kansas because the harm done to the media was too great and the prosecutor did not make a sufficient attempt to obtain the information through alternative channels.

But all of those wrong turns led to a right one: Kansas became the thirty-eighth state to enact a shield law. ${ }^{493}$ Under the new law, the subpoenas issued to O'Brien also likely would have been quashed. Although some of the information the prosecutor sought arguably was "relevant" in the broadest sense, he could not overcome the other elements of the test that were included in the new law: he had not sought the information through alternative channels and could not identify a

493. Cristina Abello, Kansas Governor Signs New Shield Law, RePs. COMMITTEE FOR FreEDOM OF THE PRESS (Apr. 15, 2010), http://www.rcfp.org/node/97942. 
sufficiently "compelling interest" to force the judge to order disclosure.

A shield law will not solve all problems for all reporters. But for O’Brien, it would have simplified her case. Many legal fees and much time could have been saved simply because the procedure courts must follow when considering the reporter's privilege not to testify would have been clearly identified. And given the test included in the new shield law and the facts of O'Brien's case, the outcome in the trial court likely would have been different: her confidential information perhaps would have remained just that. If so, she might still be employed by the Dodge City Daily Globe today.

In the end, O'Brien paid a high price for her use of a confidential source. She was subpoenaed, was made a poster child for media advocates, foolishly decided to skip court, and eventually lost her job following a very public and bitter dispute with her newspaper. A shield law might have saved her much of the trouble. But without her case, Kansas almost certainly would not have a shield law today. That is a significant silver lining in the otherwise difficult story of Claire O'Brien. The new shield law has been described by national observers as strong and by Kansas media advocates as precisely the type of protection they have sought for years.

But the outcome of the case for O'Brien was terribly unfortunate. No matter how it happened, it is a shame that a reporter who stood her ground and fought for First Amendment principles is out of a jobperhaps because of it. Following her termination in Dodge City, O'Brien found work as a freelance reporter for other newspapers in central and southwest Kansas. ${ }^{494}$ But as one final, ironic post-script, the convoluted case did produce at least one line for her résumé. Two weeks after she was terminated, she won four reporting awards from the Kansas Press Association. ${ }^{495}$ Her recognition included a first-place award for the story that led to so much controversy_ and to the enactment of a Kansas shield law. ${ }^{496}$

494. Billy Dennis, Fired by GateHouse, Kansas Reporter Is Back at Work . . as a Freelance Correspondent, PEORIA PUNDIT (Apr. 15, 2010), http://pundit.blogpeoria.com/2010/04/15/fired-bygatehouse-kansas-reporter-is-back-at-work-...-as-a-freelance-correspondent/.

495. Daily Globe Wins Six Awards in State Contest, Dodge City Daily Globe, Mar. 23, 2010, http://www.dodgeglobe.com/business/x427983243/Daily-Globe-wins-six-awards-in-state-contest.

496. Id. ("O'Brien also took third-place honors in the feature, investigative and local business story categories.”). 